\title{
ORIGINAL ARTICLE \\ Rising incomes and inequality of access to infrastructure among Latin American Households
}

\author{
Marianne Fay ${ }^{l}$ and Stéphane Straub ${ }^{2 \# *}$
}

\begin{abstract}
${ }^{1}$ World Bank, United States
${ }^{2}$ Toulouse School of Economics, University of Toulouse Capitole, Toulouse, France

\# We thank Charles Fox and the World Bank LAC Stats team for help with data access, María-José Graña for outstanding research assistance, and Uwe Deichmann, Augusto de la Torre, and Stephane Hallegatte, and participants at the World Bank 'Unbaked and Wired' Infrastructure workshop for useful comments and suggestions.
\end{abstract}

\begin{abstract}
The question of infrastructure needs is a crucial policy one in Latin America, given evidence of large access shortfalls across all major types of infrastructure, and the increase in demand linked to the rapid growth in households' income over the past two decades. However, how much and how fast countries should invest in each of the main infrastructure areas are largely speculative, as to date, literature on investment needs has relied exclusively on aggregate data and cross-country regressions, ignoring both potential policy and supply-side differences across settings, and variations in demand along the income distribution. This paper addresses these shortcomings, providing building blocks to better assess infrastructure investment needs across the region. It does so documenting access to services and ownership of infrastructure-related durables in the water, energy, telecom, and transport areas, based on harmonized household survey data covering 1.6 million households in 14 Latin American countries from 1992 to -2012. It provides a systematic disaggregation of access and ownership rates at different levels of income and over time, and econometrically derives the country infrastructure premium, a measure of how much a household benefits from simply being located in a given country. Within countries, the results show extensive inequality of access across the income distribution, but this is also the case for households at similar levels of income across countries. Few country fundamentals appear to be significant in explaining this variability, pointing to differences in policy choices and local constraints as important determinants. The paper derives disaggregated income elasticity measures for the full set of infrastructure indicators and uses these to estimate the time that would be needed to close the remaining gap for households at different levels of the income distribution in each country under a "business as usual" hypothesis. Under that scenario, universal access appears to still be decades away for many countries in the region. The last part discusses the policy challenges, arguing that in a context in which public budgets face strong constraints and significant increases in private investment are unlikely to be forthcoming, a large part of the solution lies in refocused investment strategies, better demand management, and improved public spending efficiency.
\end{abstract}

Keywords: infrastructure; Latin America and the Caribbean; household consumption JEL Classification: H54, O54, D12 
ARTICLE INFO

Received: January 21, 2019

Accepted: March 28, 2019

Available online: April 11, 2019

*CORRESPONDING AUTHOR

Stéphane Straub, Toulouse School of Economics, University of Toulouse Capitole, France; stephane.straub@tse-fr.eu

CITATION

Fay M and Straub S (2019). Rising incomes and inequality of access to infrastructure among Latin American Households. Journal of Infrastructure,

Policy and Development, 3(1): 76-99.

doi: 10.24294 jipd.v3i1.1086

\section{COPYRIGHT}

Copyright $(C 2019$ by authors(s). This work is licensed under the Creative Commons Attribution-NonCommercial 4.0 International License (CC BY-NC 4.0). http://creativecommons.org/licenses/by/4.0/

\section{Introduction}

In Latin America, as in large parts of the developing world, aggregate indicators show that both households and firms suffer from large access shortfalls across all major types of infrastructure (Estache and Fay 2009). This situation is likely to have been exacerbated over the past two decades by the rapid growth in the share of households attaining middle-income status and the growth in demand for infrastructure services they generated (Ferreira et al. 2013, Lakner and Milanovic 2015). This makes the question of infrastructure needs a crucial one: How much and how fast should countries invest in each of the main infrastructure areas?

To date, the main methodologies used to estimate country-level infrastructure needs derive from a top-down approach based on aggregate production function or growth regressions. In these models, sector-specific elasticities are then used project either amount of investments needed to reach specific targets or infrastructure stocks corresponding to predicted gross domestic product (GDP) growth. ${ }^{1}$

Two main problems plague these estimates. First, they mostly extrapolate past relationships derived from environments in which infrastructure stock data are likely to be constrained by insufficient or mistargeted supply due to specific policy choices, as well as fiscal and administrative conditions, and do, therefore, not proxy adequately for potential demand growth. Second, by relying on aggregate country-level estimates, they are unable to factor in the fact that shortfalls, potential infrastructure demand growth, and supply constraints, all vary at different points of the withincountry income distribution.

This paper addresses these two issues, providing building blocks to better address infrastructure investment needs. First, it puts together a novel dataset, based on large scale harmonized household survey data from Latin America covering 14 countries over the 1992-2012 period, to document access to services and ownership of infrastructure-related durables in the water, energy, telecom, and transport areas. It provides a systematic disaggregation of access and ownership rates across the income distribution, allowing for an assessment of the situation of households at different levels of income and over time across the countries of the region. The results show very large inequality of access within countries.

Second, it establishes the importance of considering country-specific conditions such as differences in economic policies and supply constraints when looking at the evolution in access to infrastructure and deriving income elasticities measures to be used in projections. For a number

1 Calderón and Servén (2003) and Fay and Yepes (2003) are precursors of these lines of work, reviewed in more details in the next section. 
of indicators, the data reveal wide disparities across households at similar levels of income in different countries. We econometrically derive country infrastructure premia, which show how much a household at a specific level of the income distribution benefits from simply being located in a given country, and assess the progressivity or regressivity of infrastructure access patterns across the income distribution. We show that these premia are only partly explained by per capita GDP and are not systematically aligned with other country overall characteristics such as inequality, density, or urbanization, which means they are very likely to be for a large part policy driven.

Next, we compute the income elasticity of infrastructure access and durable ownership for our set of indicators, using a panel based on the global quantiles distribution. Consistent with the view that local conditions and constraints matter, the results display very large variations across countries, by as much as an order of magnitude, as well as along the income distribution. We also highlight an asset ownership "pecking order," by which, as their income grows, poorer households tend to acquire first a fridge, then a washing machine, and finally a car.

Given these estimates, we provide simple forecasts of the time that would be needed to close the remaining gap for households at different levels of the income distribution under a business as a usual hypothesis. The general message is rather somber: Without fundamental changes to the pace and efficiency of infrastructure delivery, universal access is in many cases still decades away. In addition, there are significant differences in this respect, even for countries and households at very similar levels of access.

The last part of the paper discusses the elements of a more effective strategy to define and address investment needs given the magnitude of that challenge. Based on the observed performance of countries in mobilizing investment in infrastructure, it argues that in a context in which public budgets face strong constraints and large increases in private investment are unlikely to be forthcoming, the solution may lie in other parts of the delivery equation. Specifically, we discuss three promising margins: Refocused investment goals, demand management, and interventions to improve public spending efficiency.

The paper is organized as follows. Section 2 reviews the related literature and shows how this paper contributes to it. Section 3 presents the data used in the analysis. Section 4 documents the evolution in infrastructure demand throughout the period in the different countries, derives the main estimation results and presents the implications for infrastructure delivery looking at the future. Section 5 discusses the policy challenges and concludes.

\section{Literature review}

For decades, the economic literature on infrastructure has mostly focused on aggregate data at the regional or more often the national level. ${ }^{2}$ Conventionally, infrastructure has either been measured through supply-side physical indicators, such as electricity generation capacity or kilometers of roads, or demand-side ones such as aggregate electricity or water connection rates. Given the fact that such data ignore both the spatial nature of and the distributional disparities in infrastructure access, the policy relevance of the conclusions has been limited (see Straub 2011 for a critical review).

2 There were of course micro-econometric studies using household-level data to look at specific local outcomes, such as Gibson and Rozelle (2003), Galiani, et al. (2005), or Dinkelman (2011), to cite only a few. More recently, the growing use of spatial data has been instrumental in generating a renewal of the field, allowing for example for local (often municipal) level infrastructure usage indicators. See Straub $(2008,2015)$ for reviews. 
As referred above, investment needs estimates have systematically been based on studies using such aggregate data. A first approach consists in using elasticities derived from macroeconometric models of the infrastructure-output relationship, to estimate the amount of investment required to reach specific targets such as GDP per capita in more advanced economies. An example is provided in Calderón and Servén (2003), who after deriving output elasticities using a production function approach calculate that over the period 1980-1997, the existing gap in infrastructure stocks between Latin America and East Asia contributed to close to one-third of the GDP per worker gap.

The most common formal models of infrastructure needs assessment rely in one way or another on Fay and Yepes (2003). There, infrastructure stocks, taken as proxies for infrastructure demand, are regressed on income per capita and additional controls capturing the productive structure of the economy, and time and country fixed effects. This reduced form sector-specific relationships are then used to predict future infrastructure stocks corresponding to predicted GDP growth. The conversion of these estimates to required investment expenditures is then based on best practice prices, augmented with annual maintenance spending estimated as a fixed percentage of the stock value. Recent applications for Latin America include Calderón and Servén (2010), Kohli and Basil (2011), Perrotti and Sanchez (2011), ECLAC (2014), and Serebrisky et al. (2015) among others. They estimate investment requirements of roughly $5 \%$ of GDP a year. ${ }^{3}$

However, there have been surprisingly few papers using micro-data to analyze systematically how infrastructure demand at the household level varies along the income distribution. As a result, little is known about the way demand for infrastructure varies with income at any point in time, and how it evolves over time as household income grows. ${ }^{4}$

A recent exception is Gertler et al., (2016), which uses household survey data in several large developing countries to document an S-shaped relationship between the income distribution and both consumer durable ownership and energy use, in the cross-section and over time as income grows. They then make use of a cash-transfer program-generated exogenous shock to incomes in Mexico to address the issue of potential demand constraints. In a related paper, Davis and Gertler (2015) analyze energy consumption using Mexican household data, looking at both the extensive margin (whether households adopt air conditioning or not) and at the intensive margin (the dollar amount of electricity consumption).

Lee et al. (2016) use an experiment to derive the demand for electricity connections among poor rural households in Kenya, and find that consumer surplus is far less than total costs at all price levels, suggesting that residential electrification may reduce social welfare - at least in the absence of externalities.

Our contribution is the first to systematically document infrastructure access and asset ownership at the household level in Latin America. The Socio-Economic Database for Latin America and the Caribbean (SEDLAC) database provides a harmonized sample of surveys, allowing for the comparison of households at similar levels of income across a panel of 14 countries over 20 years in the four main infrastructure sectors. While the household surveys used here are not following the same households over time, we are able to construct a pseudopanel by grouping households by

3 See Rozenberg and Fay (2019) for a recent contribution that highlights alternative approaches to defining infrastructure investment needs across sectors.

4 See Hooper et al. (2018) for an analysis of the relationship between inequality and infrastructure investment, using aggregate US state-level data. In addition, infrastructure investments may benefit households through an income effect, in particular due to the increase in land prices (see for example Diao et al., 2017). 
income quantiles and looking at the within-quantile evolution of infrastructure access over time. This then allows for the estimation of income elasticities of infrastructure access in a dynamic setting.

This enables us to document extensive inequality of access, within countries across the income distribution, and across countries in Latin America for households at similar levels of incomes. In addition, the scope of the dataset allows us to establish the importance of country-specific conditions such as differences in economic policy and supply constraints when looking at the evolution in access to infrastructure and deriving income elasticities measures to be used in projections and to provide differentiated estimates of the time needed to reach universal coverage across countries and income deciles. In turn, this allows for a richer policy discussion, which instead of simply putting forward large aggregate investment figures, starts by considering the necessity to redefine finer objectives, manages demand, and address gaps in investment efficiency.

This paper focuses exclusively on the extensive margin, i.e., whether households have access to services or own durables and provide descriptive evidence on infrastructure demand in a context in which household income has experienced strong and sustained growth. For lack of data, it stops short of providing insights on the intensive margin as captured by the value of consumption expenditures on these services. Finally, while it provides indirect evidence of potential binding supply constraints on the infrastructure provision side, and credit constraints on the demand side, it does not claim to systematically identify unconstrained elasticities. Addressing these issues is the object of ongoing work.

\section{Data}

We use household surveys microdata from the SEDLAC, developed by The Center for Distributional, Labor and Social Studies of the University of La Plata, and in partnership with World Bank Latin America and the Caribbean Poverty and Gender Group (LCSPP).

Based on the availability of key variables related to infrastructure access and infrastructurerelated assets, we build a 5-year interval dataset for 14 countries between 1992 and 2012. ${ }^{5}$ The final dataset covers 1.6 million unique household observations and includes the surveys shown in Table 1 . Table 2 shows the coverage by country and variable.

The main variables of interest are the per capita household income adjusted by purchasing power parity, in 2005 US dollars, and infrastructure. Income here includes labor and non-labor income as well as the imputed rent of owner-occupied housing. Infrastructure is measured through a set of dummies related to access to water, sewerage, electricity, fixed and mobile phones, and internet access. Another set of dummies indicates households' ownership of infrastructure-related appliances and assets. We focus on the following variables: Refrigerators, washing machine, television, computer, car, and motorcycle.

The use of access/ownership dummies means that we are bound to concentrate on the extensive margin, i.e., on whether households are connected or use a service or not, but are unable to offer insights on the intensive margin due to the absence of specific expenditure data. ${ }^{6}$

Finally, we add a number of standard country-level variables such as GDP per capita, income inequality, population density, and urbanization, all from the World Bank Indicators database.

5 We allow for $+/-1$ year when the survey for the exact year is not available.

6 Other noteworthy limitation, common to most infrastructure data sets, is the lack of information on the quality and reliability of services. 
Table 1. Household surveys included in the database

\begin{tabular}{|l|c|c|c|c|c|}
\hline Time period & $\mathbf{1}$ & $\mathbf{2}$ & $\mathbf{3}$ & $\mathbf{4}$ & $\mathbf{5}$ \\
\hline Argentina & 1992 & 1998 & 2002 & 2007 & 2012 \\
\hline Bolivia & & & 2002 & 2007 & 2012 \\
\hline Brazil & & 1997 & 2002 & 2007 & 2012 \\
\hline Chile & 1992 & 1996 & 2003 & 2006 & 2011 \\
\hline Colombia & & 1996 & 2002 & 2008 & 2012 \\
\hline Costa Rica & 1992 & 1997 & 2002 & 2007 & 2012 \\
\hline Dominican Republic & & 1997 & 2002 & 2007 & 2011 \\
\hline Ecuador & & & 2003 & 2007 & 2012 \\
\hline Honduras & 1992 & 1997 & 2003 & 2007 & 2011 \\
\hline Mexico & 1992 & 1998 & 2002 & 2006 & 2011 \\
\hline Paraguay & & 1997 & 2002 & 2007 & 2011 \\
\hline Peru & & 1997 & 2002 & 2007 & 2012 \\
\hline El Salvador & 1991 & 1998 & 2002 & 2007 & 2012 \\
\hline Uruguay & 1992 & 1997 & 2002 & 2007 & 2012 \\
\hline
\end{tabular}

To exploit the panel dimension of the data, we split it into income quantiles, alternatively percentiles or deciles, defined by reference to the regional income distribution. ${ }^{7}$ We define quantiles corresponding to the region-wide income distribution at each date. In this way, a household at say, the $11^{\text {th }}$ percentile or the $6^{\text {th }}$ decile of the distribution in 2012 is at a similar level of income regardless of whether it is from Honduras or Chile for example. In what follows, we refer to this as the global quantiles (deciles/percentiles) distribution. ${ }^{8}$

This way of defining income class allows for easy comparisons across countries, and the disentangling of the country versus individual determinants of households' situation. Based on this, the next section examines access to infrastructure across countries and at different levels of income distribution.

\section{The demand for infrastructure}

The last decade witnessed significant changes in the shape of the income distribution of developing and emerging countries (Lakner and Milanovic 2015). In Latin America specifically, Ferreira et al. (2013) estimated that the number of people that can be considered as middle class increased by 50\% over the 2003-2009 period. They define the concept of middle class following criteria of economic security, whereby a household is considered middle class if it has a probability of falling back into poverty no larger than $10 \%$ over a 5 -year interval. This implies a middle-class income threshold of $\$ 10$ a day, which is at the $68^{\text {th }}$ percentile of the Latin American income distribution in 2009 , while the moderate poverty line of $\$ 4$ leads to $30.5 \%$ of the population falling below it.

Looking at our data and relying on a consistent sample of 14 countries for which data are available from 2002 to 2012, Latin America was characterized by important income gains across

7 Following SEDLAC practice when computing inequality measures, we drop observations reporting zero income (see CEDLAS and The World Bank, 2014).

8 We often take the semantic shortcut of referring to households "in a given quantile" when talking of those below a given threshold (e.g., in quantile 1 for those below the first quantile threshold) or between two successive ones (e.g., in quantile 5 for those between the quantiles 4 and 5 thresholds). 
Table 2. Missing indicators

\begin{tabular}{|c|c|c|c|c|c|}
\hline Variable & \begin{tabular}{|l|}
1992 \\
(7 countries)
\end{tabular} & \begin{tabular}{|l|}
1997 \\
(12 countries)
\end{tabular} & $\begin{array}{l}2002 \\
(14 \text { countries })\end{array}$ & \begin{tabular}{|l}
2007 \\
(14 countries)
\end{tabular} & \begin{tabular}{|l}
2012 \\
(14 countries)
\end{tabular} \\
\hline Water & & DOM & $\mathrm{COL}$ & $\begin{array}{l}\text { SLV (all } \\
\text { obs=1) }\end{array}$ & \\
\hline Toilet & & DOM & $\mathrm{COL}$ & & \\
\hline Sewers & ARG/CRI & DOM & $\mathrm{COL}$ & & \\
\hline Electricity & ARG & DOM & COL/URY & ARG & ARG \\
\hline Refrigerator & ARG/CHL/HND & ARG/CHL/DOM/HND & $\mathrm{ARG} / \mathrm{COL} / \mathrm{HND}$ & ARG & ARG \\
\hline $\begin{array}{l}\text { Washing } \\
\text { machine }\end{array}$ & ARG/CHL/HND & ARG/CHL/DOM/HND & ARG/COL/ECU/HND & ARG/HND & $\begin{array}{l}\text { ARG/CRI/ } \\
\text { HND }\end{array}$ \\
\hline $\begin{array}{l}\text { Landline } \\
\text { phone }\end{array}$ & $\begin{array}{l}\mathrm{ARG} / \mathrm{CHL} / \mathrm{HND} / \\
\mathrm{URY}\end{array}$ & $\begin{array}{l}\text { ARG/CHL/DOM/ } \\
\text { HND/URY }\end{array}$ & $\begin{array}{l}\text { ARG/BOL/COL/HND/ } \\
\text { URY }\end{array}$ & ARG & ARG/URY \\
\hline Cell phone & $\begin{array}{l}\text { ARG/CHL/CRI/ } \\
\text { HND/MEX/SLV/ } \\
\text { URY }\end{array}$ & $\begin{array}{l}\text { ARG/BRA/CHL/COL/ } \\
\text { CRI/DOM/HND/MEX/ } \\
\text { PRY/URY }\end{array}$ & $\begin{array}{l}\mathrm{ARG/BOL/COL/CRI/} \\
\mathrm{DOM} / \mathrm{ECU} / \mathrm{HND} / \mathrm{URY}\end{array}$ & $\begin{array}{l}\mathrm{ARG} / \mathrm{COL} / \\
\mathrm{ECU}\end{array}$ & ARG \\
\hline Computer & $\begin{array}{l}\text { ARG/CHL/CRI/ } \\
\text { HND/URY }\end{array}$ & $\begin{array}{l}\text { ARG/BRA/CHL/COL/ } \\
\text { DOM/HN D/PRY/URY }\end{array}$ & $\begin{array}{l}\text { ARG/BOL/COL/ECU/ } \\
\text { HND }\end{array}$ & ARG & ARG \\
\hline Internet & $\begin{array}{l}\text { ARG/CHL/CRI/ } \\
\text { HND/MEX/SLV/ } \\
\text { URY }\end{array}$ & $12 / 12$ & $\begin{array}{l}\text { ARG/BOL/COL/CRI/ } \\
\text { DOM/ECU/HND }\end{array}$ & $\begin{array}{l}\mathrm{ARG} / \mathrm{BOL} / \\
\mathrm{DOM} / \mathrm{ECU}\end{array}$ & ARG/DOM \\
\hline Car & ARG/CHL/HND & $\begin{array}{l}\text { ARG/BOL/BRA/CHL/ } \\
\text { COL/DO M/HND }\end{array}$ & $\begin{array}{l}\text { ARG/BRA/CHL/COL/ } \\
\text { HND }\end{array}$ & $\begin{array}{l}\text { ARG/BRA/ } \\
\text { CHL }\end{array}$ & ARG/BRA \\
\hline Motorcycle & $\begin{array}{l}\text { ARG/CHL/CRI/ } \\
\text { HND/SLV/URY }\end{array}$ & $\begin{array}{l}\text { ARG/BOL/BRA/CHL/ } \\
\text { COL/CRI/DOM/HND/ } \\
\text { SLV/URY }\end{array}$ & $\begin{array}{l}\text { ARG/BRA/CHL/COL/ } \\
\text { CRI/ECU/HND/SLV/ } \\
\text { URY }\end{array}$ & $\begin{array}{l}\text { ARG/BRA/ } \\
\text { CHL/CRI/ } \\
\text { SLV } \\
\end{array}$ & $\begin{array}{l}\text { ARG/BRA/ } \\
\text { CHL }\end{array}$ \\
\hline
\end{tabular}

the income distribution during the 2002-2012 period. Indeed, over that 10-year period, the annual growth rate of the incomes of the lowest three deciles was above $5 \%$ that of vulnerable households at above $4 \%$ and that of the top three deciles, which includes the middle class and rich households at almost $3 \%{ }^{9}$

\subsection{Access patterns in Latin America: The situation as of 2012}

This rapid income growth led to a surge in demand for home equipment and mobility, hence for infrastructure services such as water, electricity connections, and transport, and related durables such as electric appliances and vehicles. As of 2012, access and ownership rates still vary widely, as can be seen in Figure 1, which graphs Latin American average access and ownership rates by deciles, as well as average rates in the worst- and best-performing countries of the sample, respectively. ${ }^{10}$

For water, Latin American averages, which go from around $71 \%$ in decile 1 to $98 \%$ at the top of the distribution, mask wide differences, from an abysmal $19 \%$ of the poorest decile households in

9 Household surveys of the type used here typically do not include very rich individuals because of random sampling, non-response, or large under-reporting. This may lead to the figure for the growth of income of the top decile being lower than the actual one, but it is inconsequential for our purpose.

10 Average Latin American rates are simple averages over the total 420,204 households' sample. Household survey weights are used, but we do not weight by country population or otherwise. Note however that bigger countries have larger samples: the number of households varies from 4889 for Paraguay to 111,612 for Brazil, and looking only at 2012, the correlations of country sample size with population and GDP are 0.67 and 0.64 respectively. 


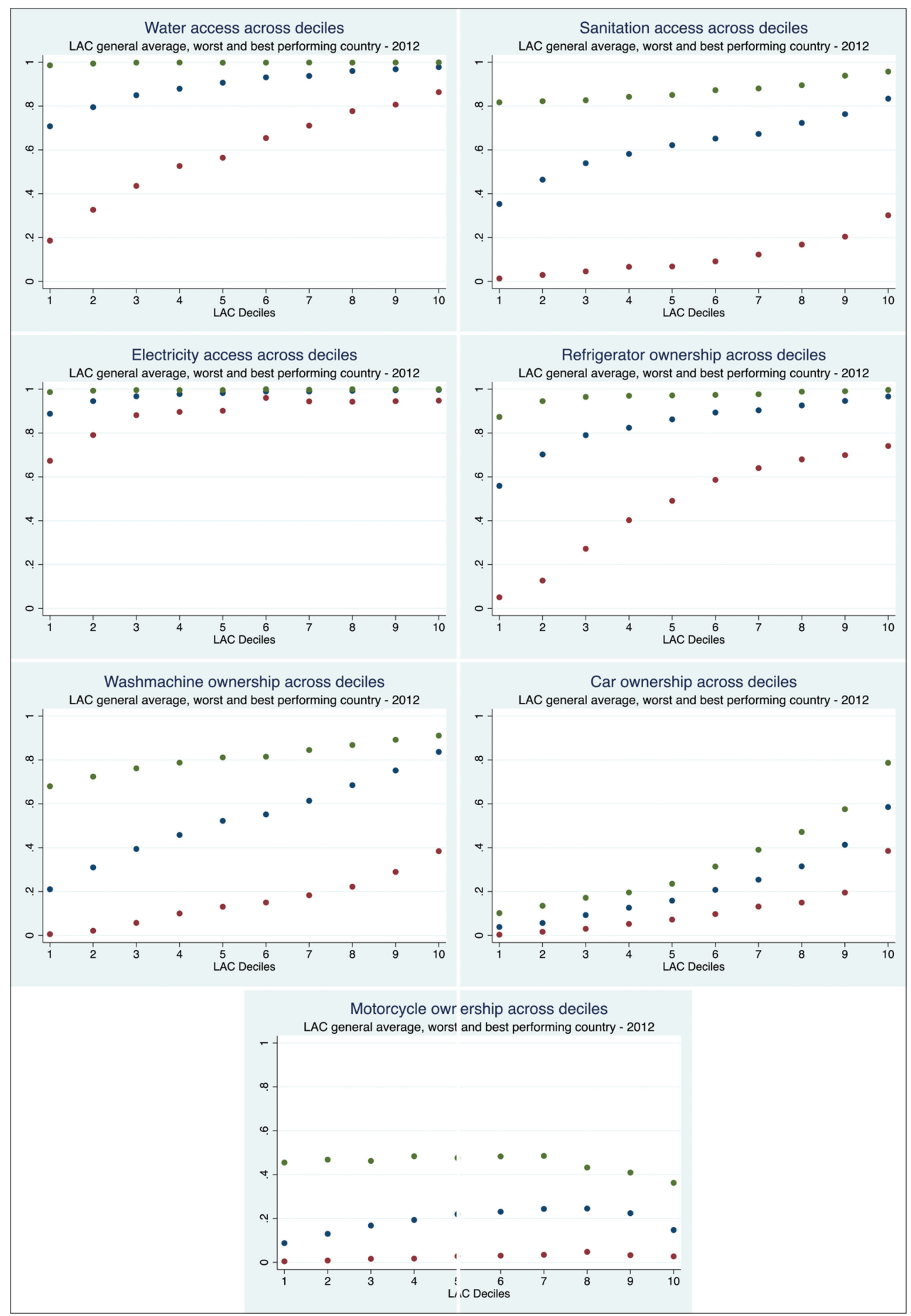

Figure 1. Infrastructure access across deciles.

In each graph, green/red dots represent the level of the best/worst performing country at each date, and the blue dots are the region average.

El Salvador having access to a source of water in the house or lot (a measure akin to basic access as defined in the Millennium Development Goal [MDGs]) to 99\% for households of similar income in Argentina. Beyond El Salvador which could be considered an outlier, three countries, Bolivia, the Dominican Republic, and Peru have barely more than half of the bottom decile households with access to water. 
The situation is more critical for sanitation. In 2012, only $1 \%$ of households in the poorest decile lived in a dwelling connected to a public sewerage system in Paraguay. With the exception of Chile, where $82 \%$ of the poorest households are connected, no country has more than $46 \%$ connections, for a Latin American average of $35 \%$ in the poorest decile. The range narrows only slightly when moving up the income distribution. At the eighth decile, roughly the lower limit for middle-class households according to Ferreira et al. (2013), average Latin American access rates are still only $72 \%$, hovering below $80 \%$ for 9 out of 14 countries.

Electricity is clearly the dimension in which the region performs best. As of 2012, regional averages start at $89 \%$ in decile 1 and reach $99 \%$ from decile 6 up. At the bottom of the distribution coverage rates start at $67 \%$, and all countries in the sample are providing above $90 \%$ coverage in all deciles, except El Salvador in the first decile, Bolivia in the first two, and Honduras and Peru in the first three.

However, these rather encouraging electricity connections figures are not exactly mirrored in appliances ownership rates. Overall, less than $80 \%$ of households in the bottom three deciles own refrigerators and less than $60 \%$ washing machines - with access considerably lower in some countries. This could be explained by a variety of factors, including credit constraints, as well as the deficient quality of electricity provision (outages and voltage stability).

Finally, despite the frequently heard claim that access to cars has increased widely, and despite increased credit availability in many countries (Fay et al., 2017), cars are still luxury goods and the average ownership rates remain modest - only exceeding $40 \%$ for the top two deciles and below $20 \%$ for a large majority of deciles and countries. This is partly compensated by larger ownership rates of motorcycles, particularly for intermediate income groups, from deciles 5 to 8 . However, these averages mask important differences across countries, as motorcycle use is mostly concentrated in the Dominican Republic, Colombia, Paraguay, and Uruguay.

The numbers above show that household income alone has limited explanatory power when it comes to infrastructure access. However, how much of infrastructure access is explained by households' country of residence, and how does this vary along the income distribution? We start with a simple decomposition, focusing on the situation in $2012 .{ }^{11}$ Consider that access to a specific type of infrastructure service A in country $\mathrm{c}$ is given by:

$$
D_{i c}^{A}=\alpha+\theta_{c}+\varepsilon_{i c}
$$

Where $D^{A}{ }_{i c}$ is the average access to infrastructure asset $\mathrm{A}$, in country c, by households in income percentile $\mathrm{i}, \theta_{c}$ is country fixed effects, $\alpha$ is a constant, and $\varepsilon_{i c}$ is the error term.

The results are in Table 3. Each cell in Panel A reports the R-squared from the estimation of (1) using the percentiles of the infrastructure service access/assets indicated at the top of the column. Given the large number of indicators, we discuss the results referring to infrastructure "clusters," concentrating on indicators for which coverage is large enough:

- The water cluster, which includes access to water, sewerage, and a toilet connected to a sewerage system or a septic tank;

- The electricity cluster, including access to electricity and ownership of the following assets: Refrigerator, washing machine, and television;

11 See Milanovic (2015) for an application to inequality. Note however that our approach differs in that this paper compares country-level quantiles, which correspond to different levels of income, whereas we use a common income distribution and look at differences in infrastructure access for households at the same level of income. 


\begin{tabular}{|c|c|c|c|c|c|c|c|c|c|c|c|c|c|c|c|c|}
\hline & 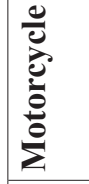 & $\begin{array}{l}\tilde{N} \\
\infty \\
0 \\
0\end{array}$ & & & ? & & & $\begin{array}{l}\overrightarrow{6} \\
\overrightarrow{0}\end{array}$ & $\mid \begin{array}{l}0 \\
0 \\
0 \\
0 \\
0\end{array}$ & $\begin{array}{l}8 \\
\text { N̦ } \\
\text { o }\end{array}$ & $\begin{array}{l}\tilde{J} \\
\bar{\Xi} \\
\dot{0}\end{array}$ & $\begin{array}{l}\tilde{1} \\
0 \\
0 \\
0 \\
i\end{array}$ & \begin{tabular}{l|l}
0 \\
$\stackrel{0}{v}$ \\
$\stackrel{0}{0}$
\end{tabular} & $\begin{array}{l}0 \\
n \\
\tilde{0} \\
0 \\
0\end{array}$ & $\begin{array}{l}\bar{\sigma} \\
\hat{\tilde{o}} \\
0 \\
0\end{array}$ & $\begin{array}{l}\stackrel{2}{े} \\
\text { ஸे }\end{array}$ \\
\hline & Uू & gे & & & $\circ$ & & & $\begin{array}{c}0 \\
0 \\
0 \\
1\end{array}$ & $\begin{array}{l}n \\
0 \\
0 \\
0 \\
0\end{array}$ & $\begin{array}{l}\tilde{n} \\
\hat{n} \\
0 \\
0 \\
0\end{array}$ & $\begin{array}{l}\hat{n} \\
\tilde{o} \\
0 \\
\dot{\varphi}\end{array}$ & 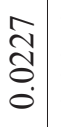 & $\begin{array}{l}0 \\
\stackrel{n}{0} \\
\dot{0} \\
\dot{0}\end{array}$ & $\begin{array}{l}\stackrel{0}{2} \\
\stackrel{2}{0} \\
\stackrel{0}{0}\end{array}$ & \begin{tabular}{l}
$\infty$ \\
$\infty$ \\
\multirow{0}{0}{} \\
$\stackrel{\varphi}{\varphi}$ \\
0
\end{tabular} & $\begin{array}{l}\bar{\kappa} \\
\text { \&े } \\
\dot{0}\end{array}$ \\
\hline & 总 & 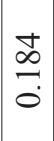 & & & $\begin{array}{l}\stackrel{2}{0} \\
\overrightarrow{0} \\
\dot{1}\end{array}$ & $\frac{\mathcal{F}}{\stackrel{\circ}{0}}$ & ָิ & 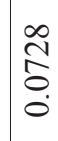 & $\stackrel{\infty}{\stackrel{\infty}{+}}$ & & \begin{tabular}{|c|}
$\mathfrak{o}$ \\
0 \\
0 \\
$\dot{0}$ \\
\end{tabular} & $\begin{array}{l}0 \\
\infty \\
0 \\
0 \\
\dot{1}\end{array}$ & \begin{tabular}{l|l} 
& 0 \\
$\grave{o}$ & \\
$\vdots$ & \\
$i$ &
\end{tabular} & $\begin{array}{l}0 \\
0 \\
0 \\
0 \\
1\end{array}$ & $\begin{array}{l}n \\
\tilde{n} \\
\tilde{0} \\
0 \\
1\end{array}$ & $\stackrel{9}{\exists}$ \\
\hline & 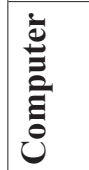 & 5 & & & $\mid \begin{array}{l}0 \\
⿱ 亠 䒑 \\
2 \\
0 \\
0\end{array}$ & $\frac{+}{2}$ & $\frac{\text { 守 }}{0}$ & $\stackrel{m}{=}$ & $\begin{array}{l}+ \\
2 \\
0 \\
0 \\
0 \\
\dot{0}\end{array}$ & $\begin{array}{l}\infty \\
n \\
\infty \\
0 \\
0 \\
0 \\
0\end{array}$ & $\begin{array}{l}0 \\
2 \\
2 \\
0 \\
0 \\
0\end{array}$ & $\begin{array}{c}\tilde{\Xi} \\
\stackrel{0}{0}\end{array}$ & $\begin{array}{l}n \\
2 \\
\tilde{\delta} \\
\vdots \\
\dot{1} \\
1\end{array}$ & $\begin{array}{l}n \\
\infty \\
5 \\
0 \\
0 \\
1\end{array}$ & $\begin{array}{l}\tilde{1} \\
0 \\
0 \\
0 \\
0 \\
1\end{array}$ & m. \\
\hline 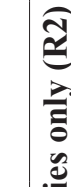 & 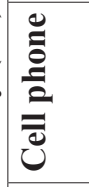 & ईे & $\mathfrak{I}$ & & $\begin{array}{l}n \\
\tilde{n} \\
0 \\
0 \\
1\end{array}$ & 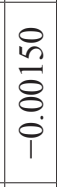 & $\begin{array}{l}\hat{a} \\
\text { ô } \\
\dot{i}\end{array}$ & 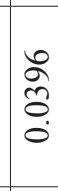 & $\begin{array}{l}\frac{1}{n} \\
\hat{n} \\
0 \\
0\end{array}$ & $\frac{\text { 导 }}{\mathbf{i}}$ & $\begin{array}{l}1 \\
\delta \\
0 \\
0 \\
i\end{array}$ & $\begin{array}{l}\approx \\
0 \\
0\end{array}$ & $\begin{array}{l}\vec{\infty} \\
\tilde{o} \\
\vdots \\
\dot{1}\end{array}$ & $\begin{array}{c}0 \\
\overline{0} \\
\end{array}$ & $\begin{array}{l}0 \\
0 \\
0 \\
0 \\
0 \\
0\end{array}$ & $\begin{array}{c}\infty \\
\stackrel{0}{\leftrightarrows} \\
\stackrel{9}{0}\end{array}$ \\
\hline 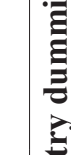 & 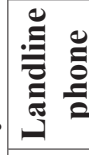 & $\frac{n}{0}$ & 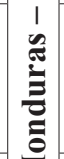 & & $\mid \begin{array}{c}n \\
0 \\
0 \\
i\end{array}$ & $\begin{array}{l}\infty \\
\stackrel{\infty}{0} \\
0 \\
\dot{\varphi}\end{array}$ & $\begin{array}{l}\frac{a}{\hat{0}} \\
\dot{0}\end{array}$ & $\begin{array}{l}8 \\
0 \\
8 \\
0 \\
0\end{array}$ & $\stackrel{m}{0}$ & $\underset{\oplus}{\stackrel{\oplus}{\varphi}}$ & $\begin{array}{l}0 \\
\infty \\
\infty \\
0 \\
0 \\
0\end{array}$ & $\begin{array}{l}\vec{m} \\
\stackrel{0}{0}\end{array}$ & $\begin{array}{c}\vec{J} \\
\vec{i}\end{array}$ & $\begin{array}{l}\infty \\
\stackrel{\sim}{n} \\
\stackrel{0}{0}\end{array}$ & $\begin{array}{c}0 \\
\tilde{\tilde{o}} \\
\dot{0} \\
\dot{\varphi}\end{array}$ & \\
\hline 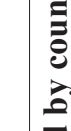 & $\geq$ & 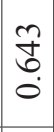 & 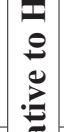 & & $\mid \begin{array}{l}n \\
\alpha \\
0 \\
0 \\
0 \\
0\end{array}$ & 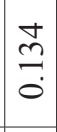 & $\begin{array}{l}8 \\
\text { ?े } \\
i\end{array}$ & 吕 & $\stackrel{m}{\rightrightarrows}$ & $\frac{n}{0}$ & $\mid \begin{array}{l}\hat{n} \\
\hat{\sigma} \\
\dot{0}\end{array}$ & $\begin{array}{l}\stackrel{2}{S} \\
\stackrel{0}{0} \\
0\end{array}$ & 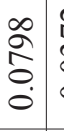 & $\begin{array}{l}\mathbb{1} \\
\hat{\tilde{\delta}} \\
0 \\
\dot{1}\end{array}$ & $\begin{array}{l}\dot{\Xi} \\
\stackrel{0}{0} \\
\dot{0}\end{array}$ & $\stackrel{\vec{c}}{\overrightarrow{0}}$ \\
\hline 总 & 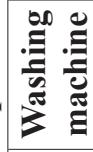 & $\begin{array}{l}1 \\
0 \\
0 \\
0 \\
0\end{array}$ & 离 & & $\mid \begin{array}{l}0 \\
n \\
n \\
i \\
1\end{array}$ & $\begin{array}{l}\vec{a} \\
\overrightarrow{0} \\
i\end{array}$ & $\begin{array}{l}2 \\
\hat{o} \\
0 \\
\dot{0}\end{array}$ & 寺 & & $\stackrel{f}{\mathcal{I}}$ & $\begin{array}{l}\infty \\
0 \\
\tilde{1} \\
0 \\
1 \\
1\end{array}$ & $\begin{array}{l}\hat{\imath} \\
\hat{n} \\
\stackrel{0}{0} \\
1\end{array}$ & & $\begin{array}{l}\stackrel{8}{\circ} \\
\stackrel{n}{0} \\
\text { 1 }\end{array}$ & 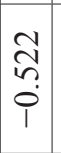 & $\begin{array}{l}0 \\
\text { in } \\
0 \\
\dot{0}\end{array}$ \\
\hline $\begin{array}{l}\frac{\pi}{\pi} \\
\frac{\pi}{\pi} \\
\frac{\pi}{3}\end{array}$ & 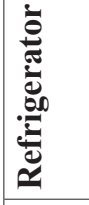 & 趈 & 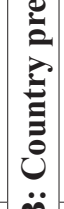 & & $\frac{0}{2}$ & ָ̃ & $\stackrel{\Re}{\stackrel{2}{0}}$ & 흥 & $\frac{\Omega}{0}$ & 命 & $\begin{array}{l}0 \\
\infty \\
2 \\
0 \\
0\end{array}$ & $\begin{array}{l}10 \\
8 \\
0 \\
0\end{array}$ & \begin{tabular}{c}
$\frac{\pi}{2}$ \\
\hdashline \\
\end{tabular} & 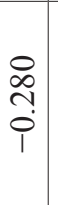 & $\begin{array}{l}0 \\
0 \\
0 \\
0 \\
0 \\
1\end{array}$ & $\stackrel{\widetilde{N}}{\tilde{0}}$ \\
\hline שֶّ & 葛 & 苞 & 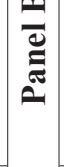 & & $\mid \begin{array}{c}\vec{\sim} \\
\vdots \\
0 \\
0\end{array}$ & $\begin{array}{l}\stackrel{8}{2} \\
\infty \\
0 \\
0\end{array}$ & $\begin{array}{l}n \\
\tilde{n} \\
\infty \\
0 \\
0\end{array}$ & $\begin{array}{l}1 \\
\infty \\
0 \\
0\end{array}$ & $\mid \begin{array}{l}\infty \\
+ \\
\infty \\
0 \\
0 \\
0\end{array}$ & $\begin{array}{l}\stackrel{R}{0} \\
\stackrel{8}{0} \\
\dot{0}\end{array}$ & $\begin{array}{l}\hat{n} \\
0 \\
0 \\
0\end{array}$ & $\begin{array}{l}\overline{1} \\
\infty \\
0 \\
0 \\
0\end{array}$ & \begin{tabular}{l|l}
$m$ & \\
0 & \\
0 & \\
$\dot{0}$ &
\end{tabular} & $\begin{array}{l}n \\
0 \\
0 \\
0 \\
1\end{array}$ & 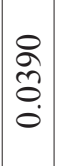 & $\begin{array}{l}\stackrel{P}{\infty} \\
\infty \\
0 \\
0\end{array}$ \\
\hline 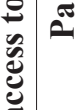 & 萢 & & & 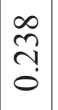 & 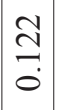 & $\begin{array}{l} \pm \\
0 \\
0 \\
0\end{array}$ & $\begin{array}{l}\text { 尺 } \\
\text { ?̦ } \\
0\end{array}$ & $\underset{\substack{n \\
0}}{0}$ & $\frac{\infty}{\tilde{m}}$ & $\vec{n}$ & $\vec{n}$ & $\begin{array}{c}m \\
\hat{\infty} \\
0 \\
0 \\
0\end{array}$ & $\begin{array}{c}q \\
⿱ \\
m \\
i\end{array}$ & $\begin{array}{c}\stackrel{0}{+} \\
0\end{array}$ & $\mid \begin{array}{l}1 \\
\tilde{b} \\
0 \\
0\end{array}$ & $\begin{array}{l}\hat{N} \\
\hat{\sigma} \\
0 \\
0\end{array}$ \\
\hline & $\frac{\bar{e}}{\stackrel{\overrightarrow{0}}{e}}$ & & & $\underset{\hat{N}}{\hat{N}}$ & $\mid \begin{array}{l}0 \\
0 \\
0 \\
0 \\
0\end{array}$ & $\begin{array}{c}\infty \\
0 \\
0 \\
0 \\
0\end{array}$ & 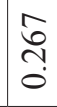 & İ & $\begin{array}{l}\overrightarrow{\tilde{J}} \\
\tilde{0}\end{array}$ & $\begin{array}{l}\bar{n} \\
0 \\
0\end{array}$ & $\begin{array}{l}n \\
\hat{ָ} \\
0\end{array}$ & $\begin{array}{l}\bar{\sigma} \\
\text { ¿̦ } \\
\dot{0}\end{array}$ & $\begin{array}{l}\tilde{m} \\
\stackrel{0}{0}\end{array}$ & $\begin{array}{l}\hat{\hat{\alpha}} \\
\infty \\
0 \\
0\end{array}$ & 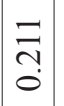 & 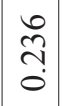 \\
\hline & $\frac{\dot{\bar{J}}}{\bar{\pi}}$ & & & $\begin{array}{c}n \\
\hat{0} \\
0\end{array}$ & $\begin{array}{l}\hat{\hat{O}} \\
\infty \\
0 \\
0 \\
i\end{array}$ & $\begin{array}{l}\hat{0} \\
0 \\
0 \\
0\end{array}$ & $\begin{array}{l}\stackrel{P}{\mathcal{2}} \\
\text { ô. } \\
\stackrel{0}{0}\end{array}$ & $\begin{array}{l}0 \\
\infty \\
0 \\
0 \\
0\end{array}$ & $\begin{array}{l}+ \\
\stackrel{2}{\infty} \\
0 \\
0 \\
0\end{array}$ & $\vec{\sigma}$ & $\begin{array}{c}n \\
\hat{n} \\
8 \\
\dot{\delta}\end{array}$ & $\begin{array}{c}2 \\
\dot{\infty} \\
\dot{0}\end{array}$ & $\begin{array}{l}0 \\
\dot{7} \\
\dot{0} \\
\dot{1}\end{array}$ & $\begin{array}{c}\stackrel{\vartheta}{\Xi} \\
\overrightarrow{0}\end{array}$ & $\begin{array}{l}9 \\
\dot{o} \\
\dot{q} \\
i\end{array}$ & $\begin{array}{l}n \\
\infty \\
0 \\
0 \\
0\end{array}$ \\
\hline & 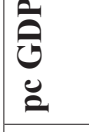 & & & & $\begin{array}{l}\frac{2}{n} \\
n\end{array}$ & $\begin{array}{l}尺 \\
a \\
\vdots \\
\Xi\end{array}$ & $\begin{array}{l}0 \\
\stackrel{0}{0} \\
\stackrel{1}{2}\end{array}$ & $\begin{array}{l}\text { \& } \\
\infty \\
=\end{array}$ & $\begin{array}{l}2 \\
2 \\
n \\
n\end{array}$ & $\begin{array}{l}\tilde{N} \\
\tilde{0} \\
0\end{array}$ & $\frac{\infty}{R}$ & $\begin{array}{l}0 \\
\cdots \\
0\end{array}$ & $\begin{array}{cc}\vec{n} & \\
\infty \\
0 \\
0\end{array}$ & $\begin{array}{l}n \\
n \\
n\end{array}$ & $\begin{array}{l}0 \\
\stackrel{2}{n} \\
=\end{array}$ & $\begin{array}{l}\underset{\tilde{\sigma}}{+} \\
\infty \\
\underline{-}\end{array}$ \\
\hline & 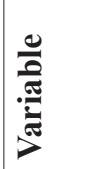 & & & 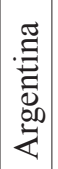 & 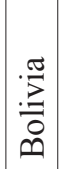 & $\begin{array}{l}\overline{\mathbb{N}} \\
\overline{\mathscr{n}} \\
\bar{\varphi}\end{array}$ & 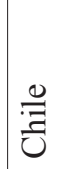 & $\begin{array}{l}\cdot \frac{\pi}{0} \\
\frac{0}{0} \\
0 \\
0\end{array}$ & 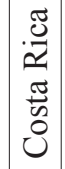 & 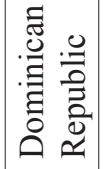 & $\begin{array}{c}\tilde{s} \\
\tilde{z} \\
\tilde{J} \\
\tilde{U} \\
\tilde{I}\end{array}$ & 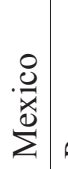 & 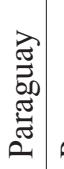 & : & $\left|\begin{array}{c}\bar{\pi} \\
\frac{\pi}{\pi} \\
\tilde{n} \\
\bar{n} \\
\overline{I 1}\end{array}\right|$ & 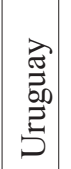 \\
\hline
\end{tabular}


- The Information and Communication Technologies (ICT) cluster, which includes landline and cell phones, internet access, and ownership of a computer;

- The transport cluster, including ownership of cars and motorcycles.

The results indicate that a large share of the variability in individual percentile access to infrastructure services and consumption of related assets can be explained by country residence only. For the water cluster, country dummies explain between $40 \%$ and $67 \%$ of the variability of individual percentile-level access across Latin America.

The electricity cluster displays an equally strong explanatory power of locational aspects, with country dummies explaining $33 \%$ of the variability in access to electricity, and between 54\% (for refrigerators), $64 \%$ for television, and $66 \%$ (for washing machines) of the variability in related assets ownership. The fact that country dummies explain more of the difference in durables than infrastructure access itself, despite the fact that access may be constrained, may be related to differences in access to credit or cost, such as variation in the taxation of durables across countries.

The outcomes for the ICT cluster indicate that 16 and $40 \%$ of landlines and cell phones variability in access are explained by location, respectively, while it is $25 \%$ for computers and $18 \%$ for internet access.

Finally, in the transport cluster, country dummies explain only $10 \%$ of the variability in ownership of cars, but this jumps to $85 \%$ for motorbikes due to the strong concentration in a few countries noted above.

Panel B presents the country premium, as given by the coefficients of the corresponding country dummy, relative to the poorest country in the sample, which in this case is Honduras. This indicates, for each indicator, the average premium related to living in each country rather than Honduras.

In Figure 2, we summarize graphically how countries perform given for example their level of development, by plotting the average premium against their 2012 per capita GDP. Honduras is the benchmark, i.e., a premium equal to zero.

For water, six countries are at or below the horizontal zero line, thus doing equal or worse than Honduras despite boasting considerably higher per capita GDP. The situation is particularly bad for El Salvador and to a lesser extent Bolivia, Peru, the Dominican Republic, Ecuador, and Paraguay. The other group of dots above the horizontal axis corresponds to more virtuous countries, although Colombia, Costa Rica, Uruguay, and Argentina appear to fare relatively better than Mexico and Chile. ${ }^{12}$

This tale of several groups of countries also characterizes the regional sanitation panorama, although the composition of these groups is slightly different, with Costa Rica, the Dominican Republic, and Paraguay now the strong underperformers, Brazil, Mexico, and Uruguay in an intermediate and rather weak position, and Bolivia, Ecuador, Peru and Colombia performing well.

Finally, for electricity, the region displays overall a much smoother concave picture, with the notable exception of Peru, whose poor performance makes it an outlier.

In addition, the use of household survey microdata allows for an unprecedented window into the relative treatment of households at different levels of the income distribution within countries. The comparison of within-country premia for each decile tells us whether the current access situation is progressive, meaning that a given country does relatively better-delivering infrastructure to the lower rather than the upper part of the distribution, or regressive (Figure 3).

12 No official figure is available for Argentina's per capita GDP around 2012. We set it at 20,000\$. 


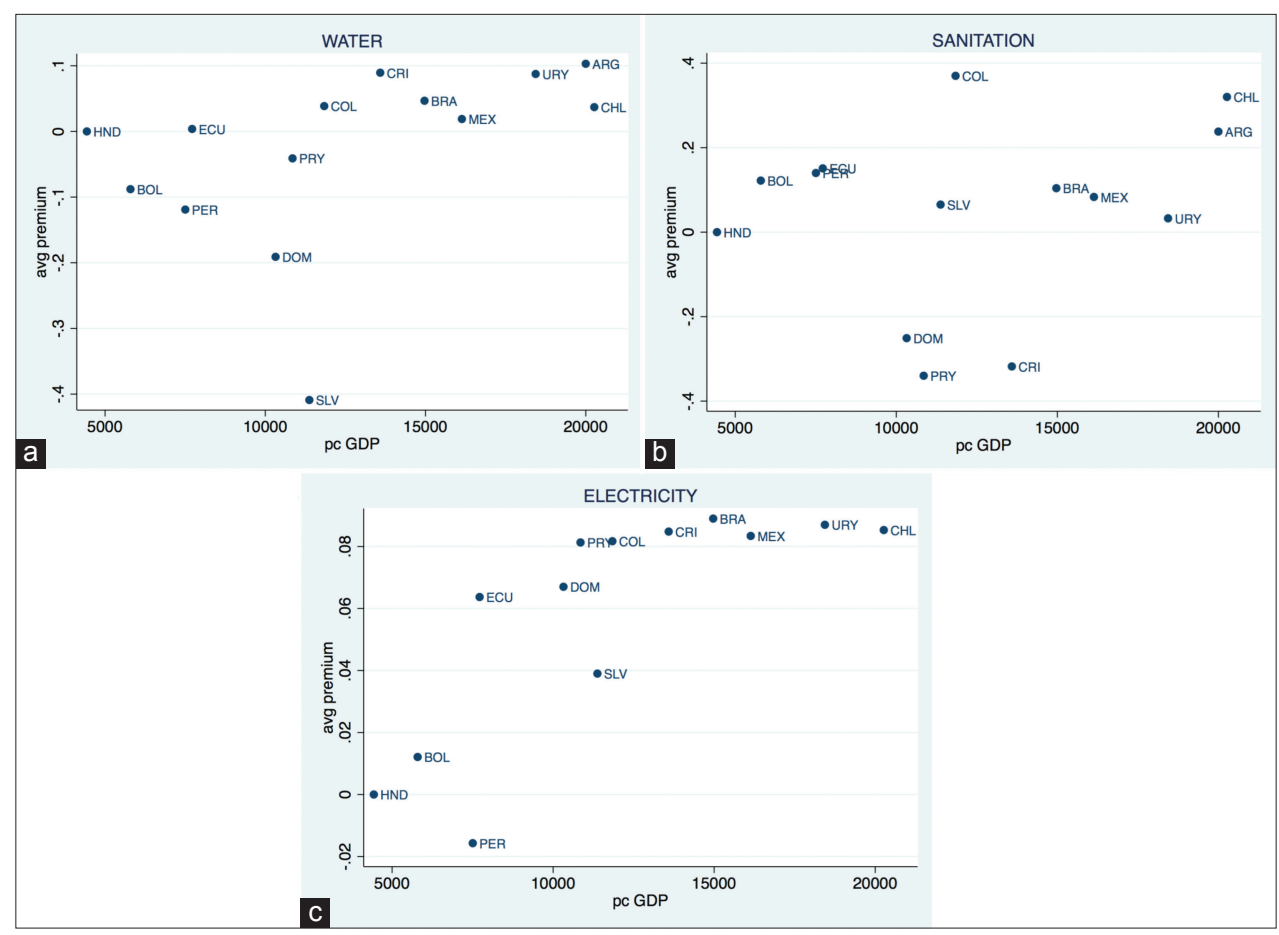

Figure 2. (a-c) Access Premium versus per capita gross domestic product.

For water, there is again a clear dichotomy, between countries that display a rather regressive pattern (El Salvador, the Dominican Republic, Peru, Bolivia, and Paraguay) and those that display the opposite pattern, especially Colombia, Costa Rica, Chile, and Argentina. Note that to a large extent, these two groups overlap with the ones that emerged from the comparison of per capita GDP and average premium in the preceding figure. What this means is that for water, given the convergence to high access levels at the top of the income distribution, overall underperformance mostly stems from a failure to address service shortfalls for the lowest income quantiles.

This situation contrasts with that of sewerage. Indeed, in this case, a few countries fare badly overall, as witnessed by their negative premium in Figure 2 above and the fact that the entire sets of decile-level premiums are negative in Figure 3, despite boasting a rather progressive pattern. This is the case of Paraguay, Costa Rica, and the Dominican Republic. The only country with a clearly regressive pattern is Peru, whose premium goes from $-1 \%$ at the first decile to $+27 \%$ at the tenth decile.

Finally, a similar story prevails for electricity, where all countries appear to have progressive delivery patterns, except again for Peru and to a lesser extent Bolivia.

The fact that location may imply such large differences in access for otherwise similar households speaks to the importance of country-level factors in determining infrastructure rollout. In particular, it begs the question of whether these locational premia can be attributed to some specific countrylevel fundamental characteristics. To address this, we estimate Equation (2):

$$
D^{A}{ }_{i c}=\alpha+X_{i c} \gamma_{l}+\varepsilon_{i c}
$$

Where $X_{i c}$ includes country-level per capita GDP, inequality (Gini), population density, and urbanization. Due to the small number of clusters (14 at most), standard errors are computed using wild cluster bootstrapping (Cameron and Miller 2015). The results are in Table 4. 


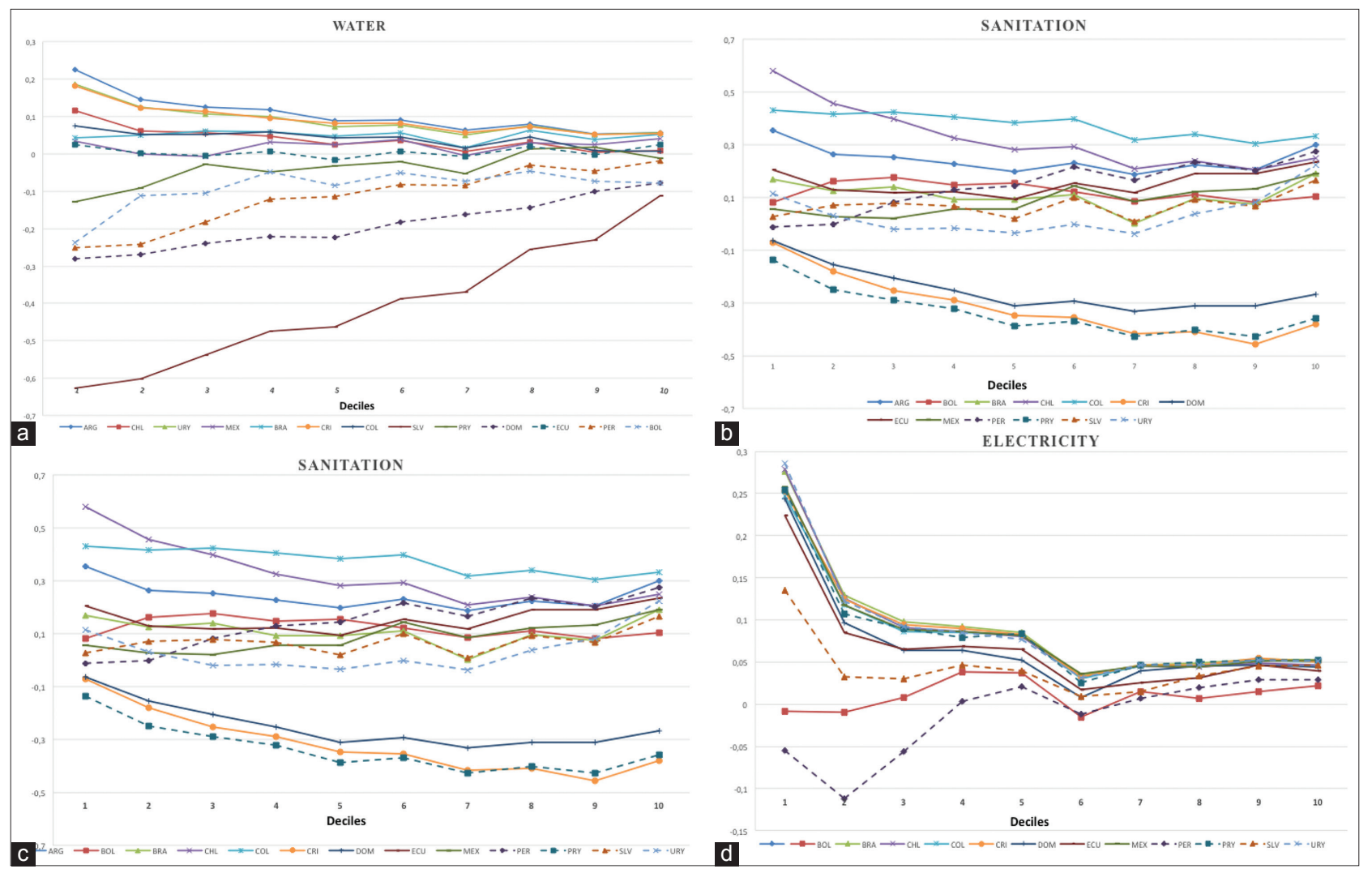

Figure 3. (a-d) Countries' access premium across the income distribution.

The elasticity of infrastructure indicators with respect to countries' per capita GDP is strong and significant for water $(0.43 * * *)$ and toilet $(0.74 * * *)$, but not for sewerage $\left(-0.75^{\mathrm{NS}}\right)$. In the electricity cluster, it is strong for electricity access $(0.24 * * *)$, refrigerator $\left(0.75^{* * *}\right)$, and washing machine (1.43) although this last one is imprecisely estimated. In the ICT cluster, it is only significant for internet access $\left(0.56^{* * *}\right)$, but is actually negative and not significant for cell phones $\left(-0.18^{\mathrm{NS}}\right)$ and computers $\left(-0.09^{\mathrm{NS}}\right)$. Finally, the elasticity of vehicle ownership is positive for cars $\left(0.23^{* *}\right)$ and motorcycles $\left(0.45^{\mathrm{NS}}\right)$.

Interestingly, other determinants do not appear to matter much. Inequality, as measured through the Gini coefficient, is almost never a significant determinant of infrastructure indicators (a higher Gini only marginally increases internet access). Higher density reduces water access and increases computer ownership. Finally, a higher urbanization rate leads to lower toilet access, lower electricity access, but higher computer ownership.

In addition, the comparison of the R-square across Tables 3 and 4 show that for most infrastructure indicators, there is a large drop in explanatory power when using specific country characteristics rather than generic country dummies. While we must be cautious in interpreting these results, they suggest that the wide disparity in access to infrastructure is only partially the result of countries' fundamentals. While richer countries have to some extent been more successful in providing infrastructure to their citizens, for example, in water, electricity, and internet, this has not been the case for other services such as sanitation or phones. The fact that aspects such as the pattern of urbanization, population density, and inequality, i.e., generic aspects that move slowly over time and are unlikely to be much affected in the short term by economic policies, also appears to have little impact, as indicated by the drop in R-square and the low significance in some estimations, 
suggests that other policy dimensions not necessarily captured by macro indicators may be key to explaining the extension of services in the past few decades. Before discussing these, we turn to the analysis of the dynamic aspects of infrastructure provision.

\subsection{The dynamic view: The elasticity of infrastructure access and durables ownership}

There is a variety of patterns in the evolution of access to infrastructure across types of services and countries in the past two decades. For example, in 1997 water access at similar levels of income differed widely across countries: Approximately $80 \%$ of households in the first decile of the Latin American income distribution had access to water in Chile, but for households at similar level of income, the rate was around 45\% in Brazil, 20\% in El Salvador, and $10 \%$ in Paraguay. Clearly, most of the disparity concentrated in the lowest part of the income distribution, as in all four countries the top decile enjoyed access rates of $90 \%$ or more, even in earlier periods.

In addition, there were wide differences in how these access rates evolved over time. For example, between 1997 and 2012, Paraguay successfully increased access rates of all income deciles above $60 \%$ and above $80 \%$ from the third decile up, while El Salvador displayed much less progress, with only households in the sixth decile and above enjoying access rates of $60 \%$ or more.

On the other hand, when looking at sewerage access rates, fewer differences are apparent between households in countries with very different levels of per capita GDP, in line with the previous result that the elasticity of per capita GDP is negative and not significant. Surprisingly, more progress appears to have been made in countries such as Peru and Bolivia, especially for households in lower deciles, than in richer countries such as Costa Rica and Uruguay.

Electricity offers a slightly more optimistic panorama. Across Latin America, access rates have converged to very high levels. Countries in which two decades ago access rates for lower deciles were as low as 20-40\%, such as Peru and El Salvador, have increased them to $70 \%$ or more across the whole income distribution, while in others such as Mexico or Brazil, universal access is now almost the rule.

While this has in some cases led to large progress in access to energy consuming devices such as refrigerators or washing machines, different patterns emerge. In Brazil, ownership of refrigerators did increase in lower income deciles following connection to the electric grid, but the process was much slower in Mexico. Similarly, comparing El Salvador and Peru, two countries with similar profiles of electrification, reveal quite different evolutions. Access to refrigerators stagnated and if anything progress was greater at the top of the income distribution in the latter, while the former witnessed a large increase in ownership.

Next, we use the complete panel, based on the global quantiles distribution, to analyze how the income elasticity of infrastructure access varies across services and countries, and within these, at different levels of the income distribution over the 1992-2012 period.

Table 5 presents two sets of results using the household survey data. First, in Panel A, we report an average Latin American elasticity given by the following estimation:

$$
D_{d c t}^{A}=\alpha+\log (\text { income })_{d c t} \gamma_{1}+\theta_{c t}+\varepsilon_{d c t}
$$




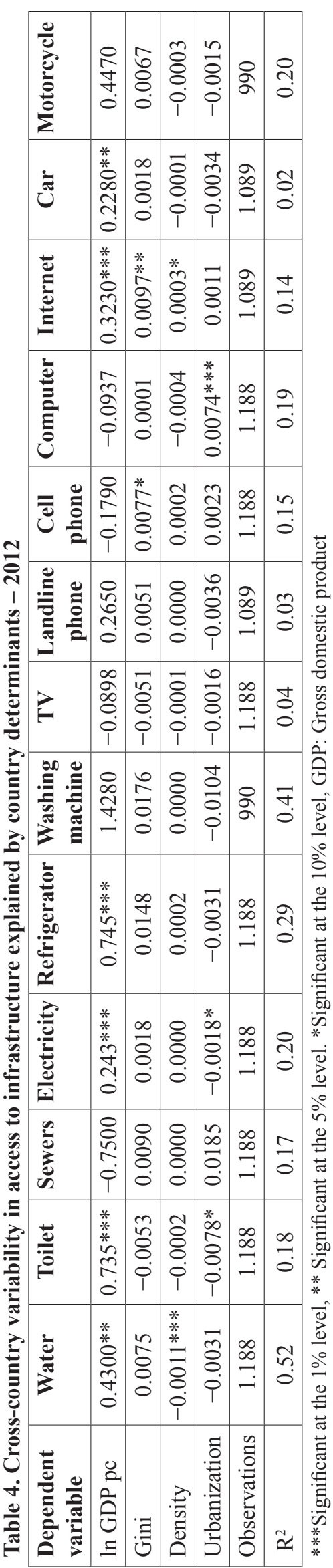

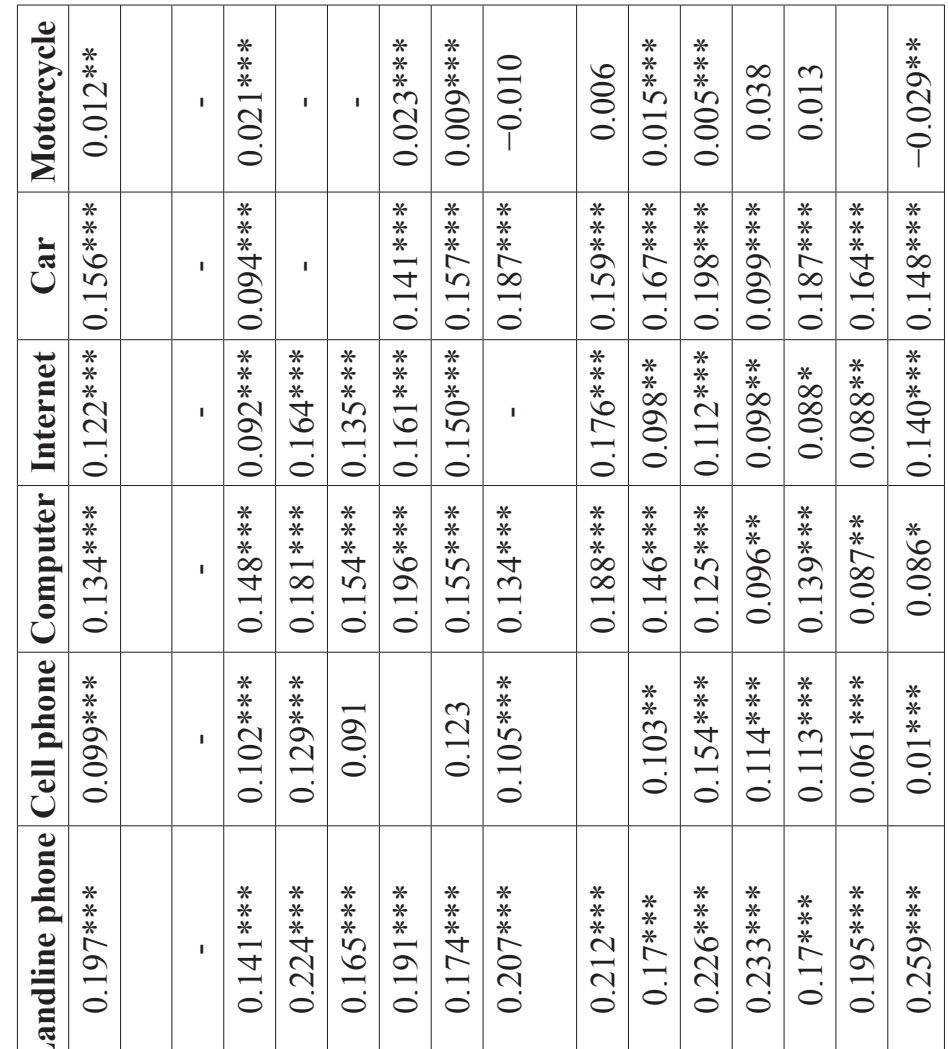

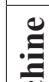

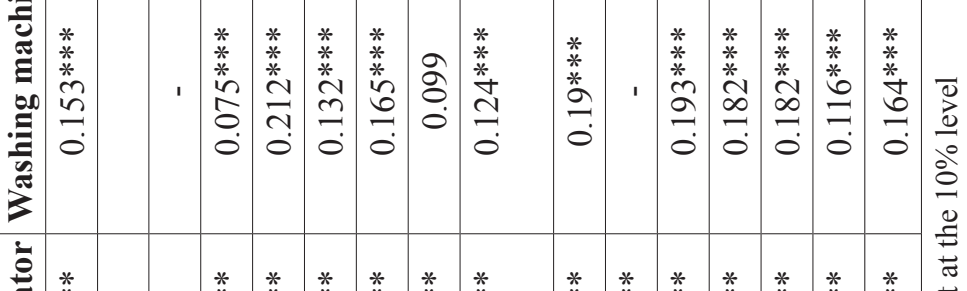

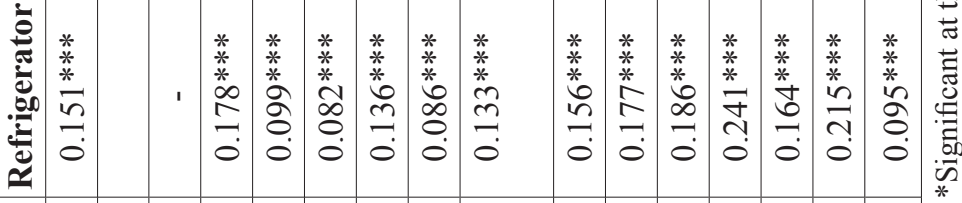

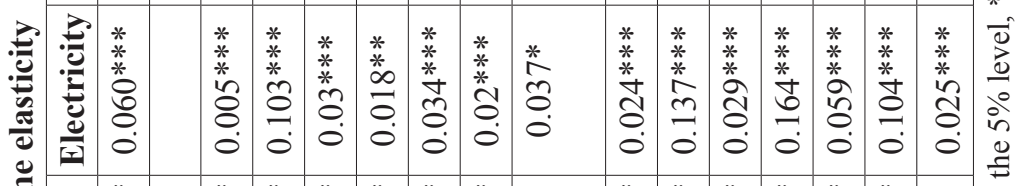

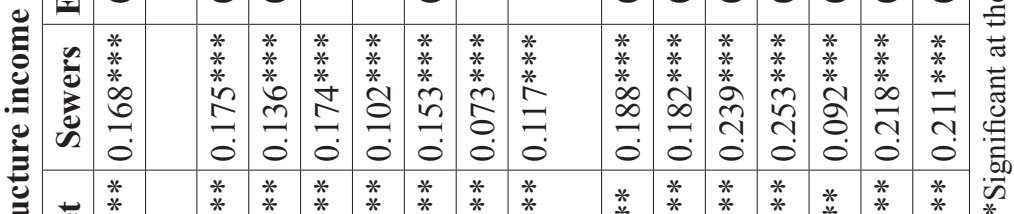

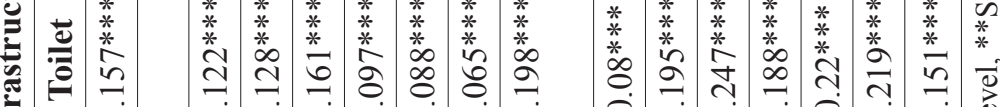

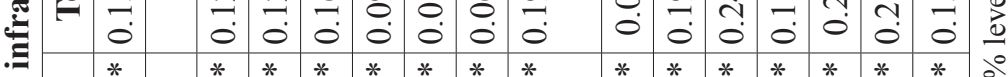

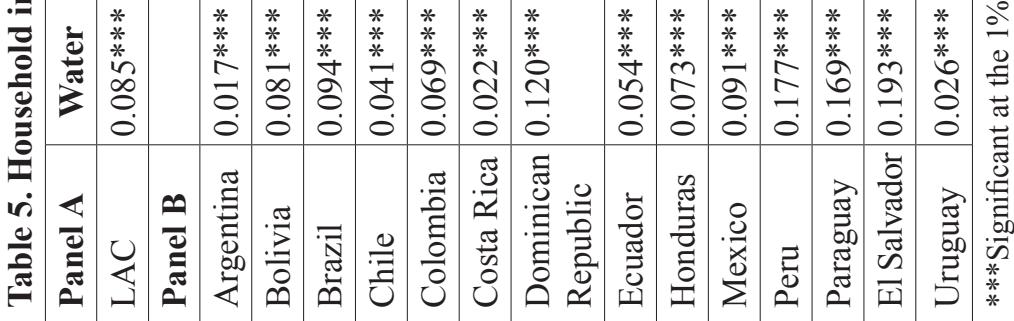


Where $D_{d c t}^{A}$ is the average access/ownership rate for infrastructure asset A, in country c, by households in income decile $\mathrm{d}$, at time $\mathrm{t}, \log (\text { income })_{d c t}$ is the average decile income, and $\theta_{c t}$ is country-time fixed effects. ${ }^{13}$

This simple specification assumes that infrastructure demand indicators at the decile level are a function of average income in that decile, and of the price of infrastructure as proxied by country-time fixed effects. The underlying assumption is thus that this price is uniform within countries in a given period, but varies over time. This is much milder than proxying prices through country dummies in the country-level panel, in effect assuming that prices are invariant across the time period. In addition, the country-time fixed effects absorb any other relevant country-level determinants, such as the ones discussed above.

Second, in Panel B, we differentiate elasticities by country, through the following specification:

$$
D_{d c t}^{A}=\alpha+\log (\text { income })_{d c t} \gamma_{1}+\left(\log (\text { income })_{d c t} \theta_{c}\right) \gamma_{2 c}+\theta_{c t}+\varepsilon_{d c t} .
$$

The elasticity of country $\mathrm{c}$ is then given by $\gamma_{1}+\gamma_{2 c}$, where $\gamma_{2 c}$ is the coefficient of the corresponding country interaction.

The resulting elasticities of access are in the expected range and strongly significant throughout. For example, the Latin American average water access elasticity is 0.08 , and country-specific values vary between 0.02 for Argentina and Costa Rica and 0.18 for Peru. The values for toilet ownership and sanitation access are higher on average, at 0.16 and 0.17 respectively, and range between 0.07 and 0.25 .

Similarly, the average Latin American electricity access elasticity is 0.06 , and it ranges from 0.01 for Argentina, 0.02 for Costa Rica and Ecuador, to 0.16 for Peru. Interestingly, elasticities for appliances ownership are in general quite larger, with 0.15 averages for refrigerators and washing machines, and ranges between 0.08 and 0.24 , indicating faster progress on the intensive margin of consumption.

In the ICT cluster, elasticities are high across all indicators. Notably, these are higher for landline phones than cell phones.

Finally, the elasticity of vehicle ownership is strong for cars, with a Latin American average of 0.16 , ranging between 0.09 in Bolivia and 0.20 in Mexico, but very small for motorcycles, with an average of 0.01 only.

Gertler et al. (2016), looking at refrigerators, suggested that the elasticities of asset ownership vary along the income distribution. The Latin American data display a rich pattern, with heterogeneity across assets. Figure 4 shows the rate increase for each decile between 2002 and 2012 for refrigerators, washing machines, and cars, as well as the related income elasticity computed separately at each decile. ${ }^{14}$ While the lowest income groups have experienced the largest increase for refrigerators, a clear inverted U-shaped pattern emerges for washing machine, with the largest increase in the middle of the income distribution. Finally, car ownership displays the opposite pattern, with access increasing mostly for the richest households.

Table 6 offers a summary comparison of the demand elasticity of infrastructure assets and access using different approaches: Latin American average, countries average, and country-level

13 Using the percentiles instead yields very similar results.

14 The income elasticity is simply computed by estimating (3) on each of the corresponding deciles subsamples. 


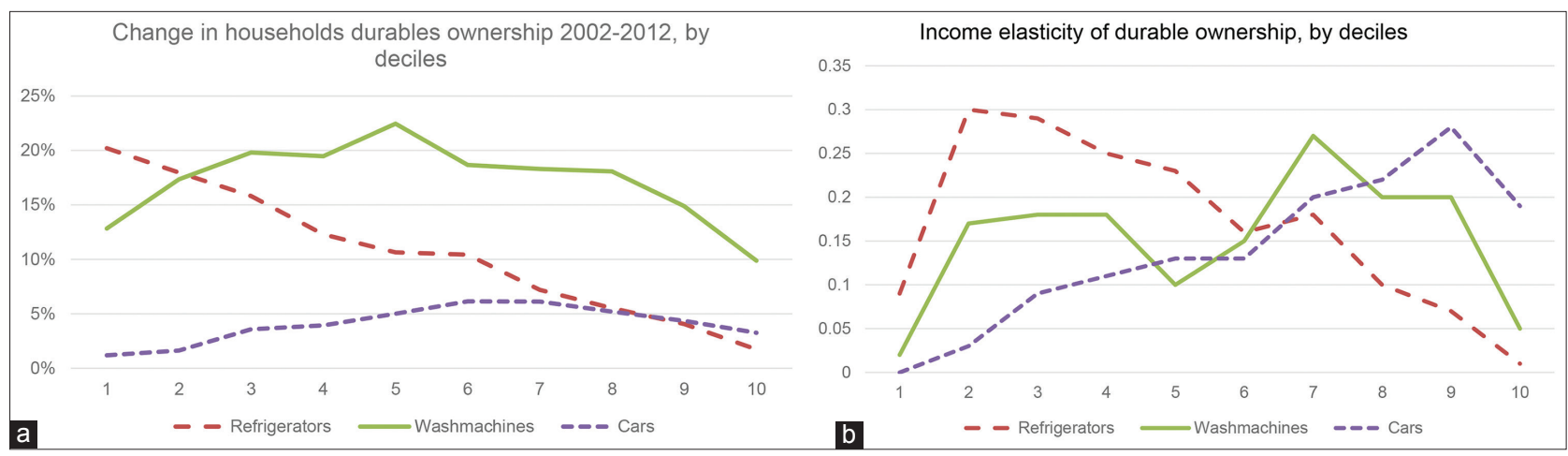

Figure 4. ( $a$ and b) Durable ownership accross the income distribution.

elasticities computed at the $10^{\text {th }}, 25^{\text {th }}, 75^{\text {th }}$, and $90^{\text {th }}$ percentiles, respectively, as well as cross-country averages from Fay and Yepes (2003) and some more recent estimations for Latin America from Perrotti and Sanchez (2011). The first immediate observation is that elasticities estimated using microdata from household surveys are smaller than those produced by macro studies.

This is especially true for elasticities of electricity access, previously computed in the $0.18-0.43$ range, while our estimate is at most 0.06 on average and $0 .{ }^{16}$ for the highest country value (Peru). Similarly, macro estimates for cell phones ownership and internet access are lower than when estimated with household survey data. The closest values are for water and sewerage, although the macro estimates tend to match the highest household data country estimates.

It is probable that this disparity is partly due to the ability of disaggregated household data to control adequately for the prices of infrastructure through country-time fixed effects, while macrodata can only include time-invariant country fixed effects. Consequently, the difference in estimates appears bigger when dealing with services for which the price matters more and has experienced large shifts over the past two or three decades, such as cell phones, internet access, and to lesser extent electricity.

Several factors are likely to be key in understanding the differences in how countries have been able to accommodate the demand pressure on infrastructure stemming from growing incomes. First, demand-side issues are likely to matter, for example, the extent that credit constraints have limited the ability of households to access infrastructure and related equipment.

In addition, on the supply side, it is likely that constraints related to limited investment and institutional capacity are playing a role. Given these likely binding supply constraints, it is enlightening to simply ask what these elasticities mean in terms of the ability of policymakers throughout the region to meet very simple universal access goals, akin to the early MDGs criteria, such as for water "access to a source of water in the house or lot." Making simple assumptions on future income growth, we can forecast for each country the number of years it would take to offer universal access to a given infrastructure service under a "business as usual" scenario.

Consider very simple mechanical projections, assuming a high-income growth scenario similar to the one of the 2002-2012 period and the average historical elasticities just discussed (Table 7). ${ }^{15}$

15 Using average elasticities is a safe approximation given that Table 5 shows they display little variations across income quantiles. Given that the values in Table 5 give "semi-elasticities", for any value $\varepsilon, \varepsilon / 100$ is the unit change in access when income increases by $1 \%$. The number of years to close the gap to full access is then given by $\mathrm{N}=(1-\mathrm{C}) /(\varepsilon / 100 . \mathrm{g})$, where $\mathrm{C}$ is the current coverage (between 0 and 1$)$, and $\mathrm{g}$ is the income growth rate. 


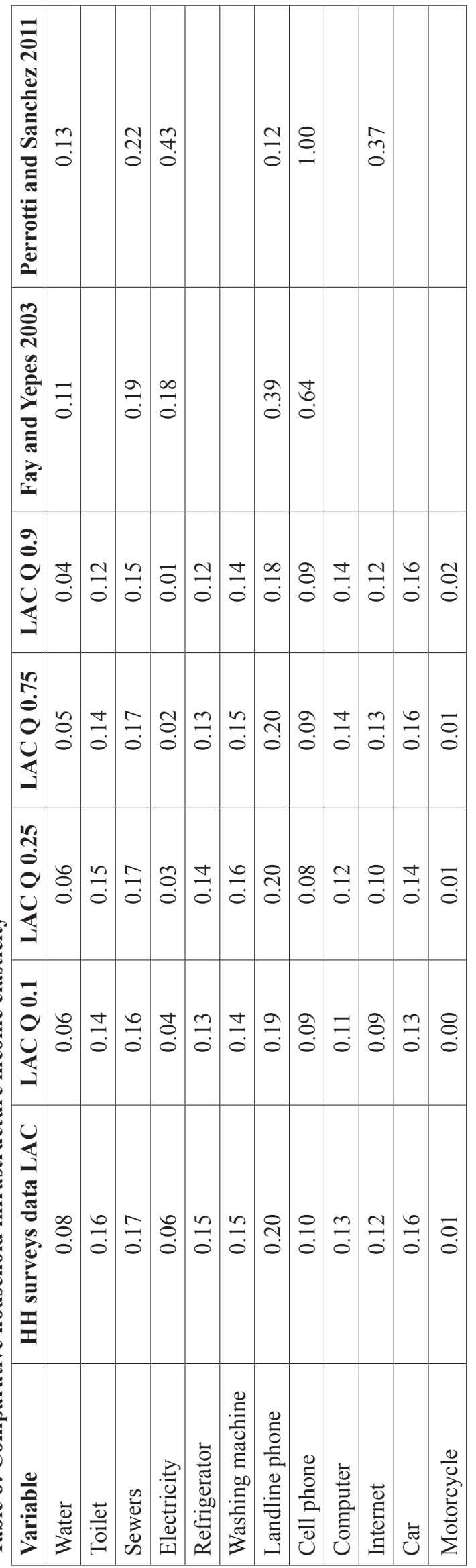

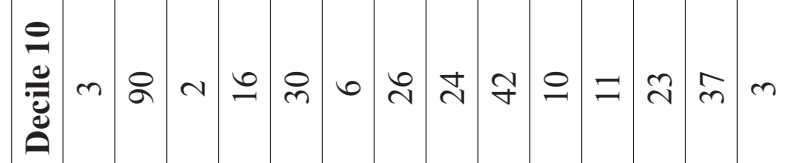

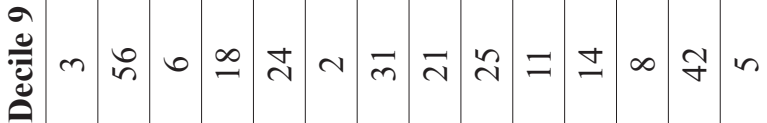

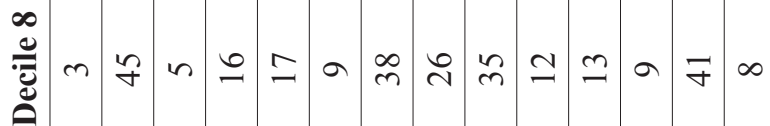

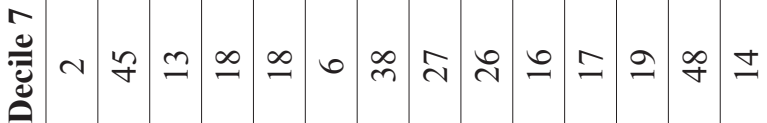

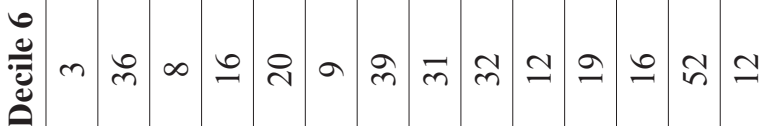

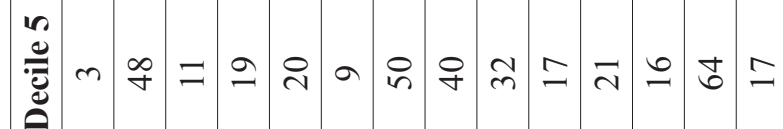

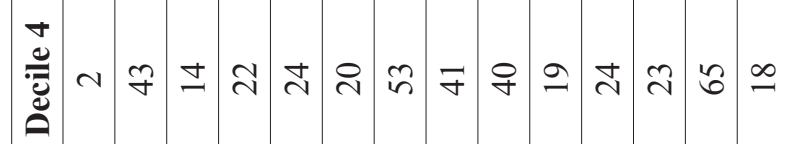

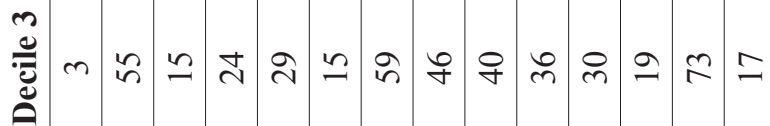

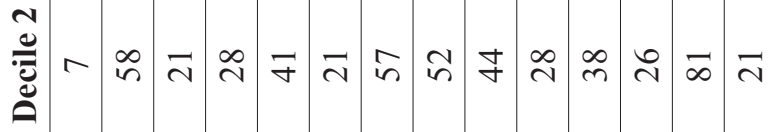

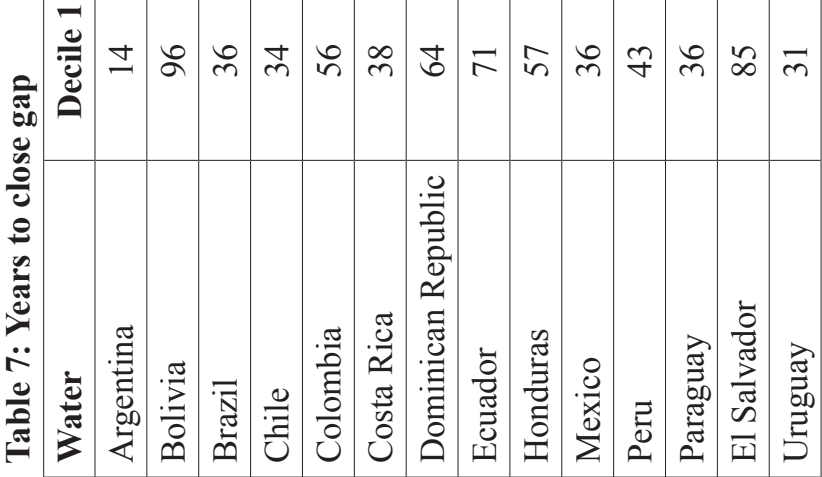




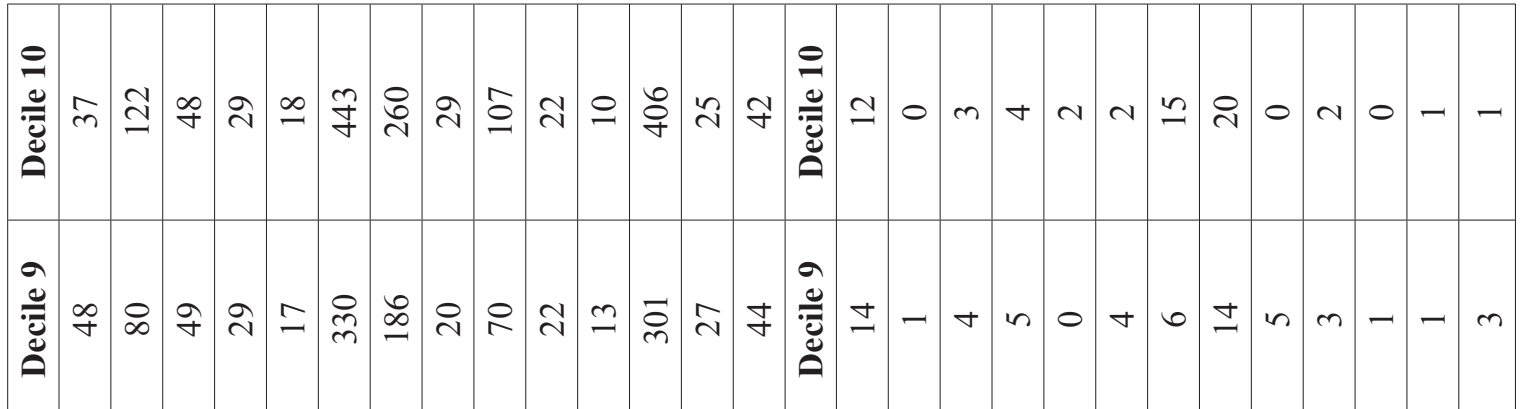

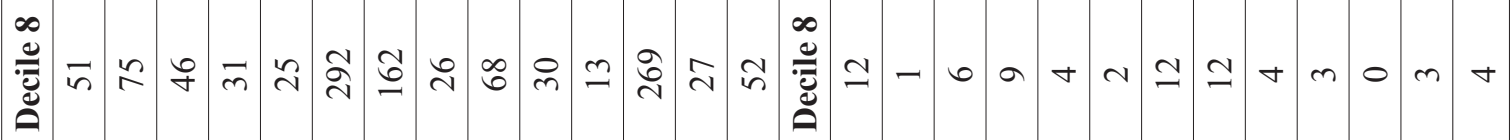

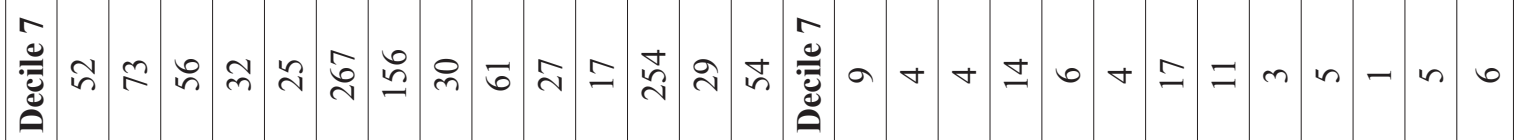

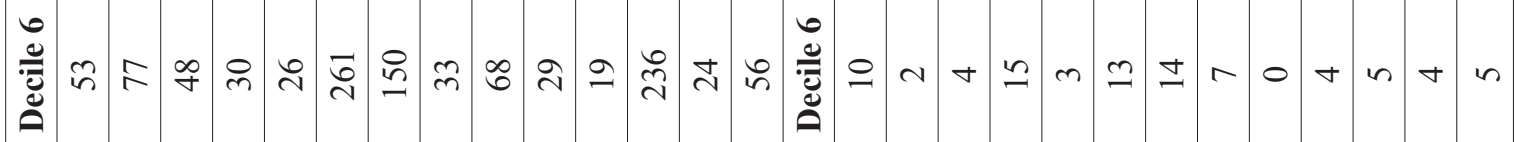
竞

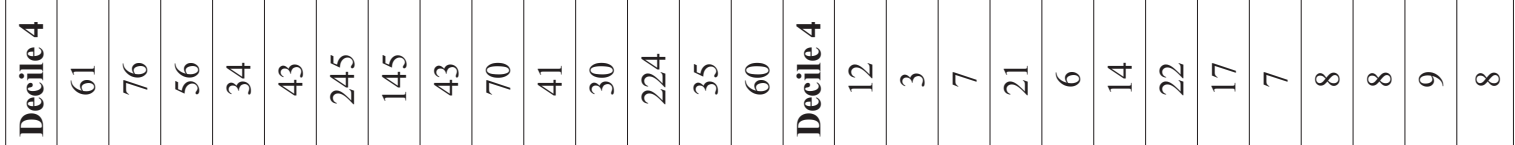

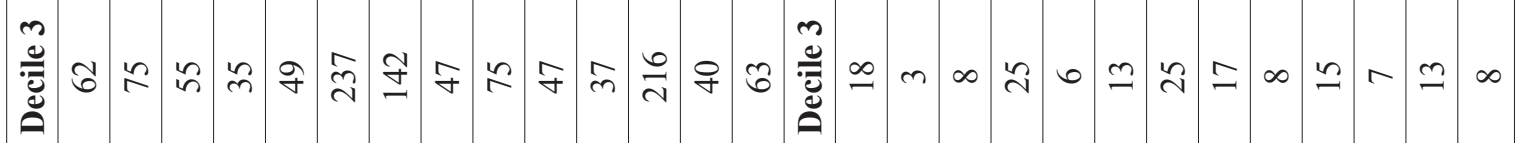
竞

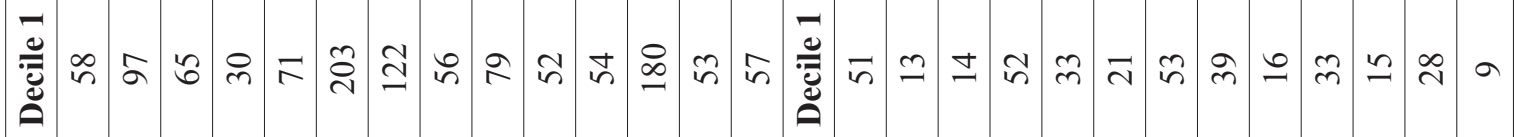


With the exception of Argentina, which is close to full access according to this criterion, the panorama is rather bleak for the lowest income deciles: At current elasticities, countries of the region will take between three and more than nine decades to provide water to the poorest $10 \%$ of households.

In a number of countries, this extends to higher quantiles and even to the top of the distribution: It will still take between 40 years in Ecuador and Honduras and 73 years in El Salvador to provide water to households in the fourth decile, i.e., above the poverty line, and from 39 years in the Dominican Republic, to 48 years in El Salvador, and 45 years in Bolivia to serve those in the middle-class range, i.e., above the seventh decile.

Of course, these projections would be even less optimistic in case of a growth slowdown. Just having the income growth rate, to $3 \%$ annually for the poorest $10 \%$ and $2.3 \%$ for households just above the poverty rate, would lead to delays in closing the water gap in decile 1 of 28 years in Argentina, 61 years in Uruguay, 72 years in Brazil and Mexico, and 86 years in Peru.

Note that the value of the elasticity plays here a crucial role. Consider the three countries with similar coverage rates at the bottom of the income distribution, Bolivia (53\%), the Dominican Republic (54\%), and Peru (54\%). The different income elasticities, of $0.08,0.12$, and 0.18 , translate into delays of, respectively 43, 64, and 96 years to achieve universal coverage among the lowest decile.

Similar exercises for sewerage reveal an even grimmer picture. Even the best-performing countries in the region are not on course to achieve universal basic sanitation (defined as a dwelling connected to a public sewerage system) in less than three decades at the seventh, "middle-class decile." At the current rate, and with high income growth, the region's best performer, Chile, would need 30 years to achieve universal sanitation for the poorest $10 \%$ of households and 31 years for middle class ones above the $70^{\text {th }}$ percentile, while Peru, due to its much more regressive pattern, would attain universal connections in 54 years at the bottom deciles and 13 years for middle-class households in the top three deciles.

Finally, for electricity, most countries are on track to achieve full connection for richer households (above the $70^{\text {th }}$ percentile) in the next 13 years or less, but delays increase to 22 years for Ecuador and Colombia at the $40^{\text {th }}$ percentile, and to more than 30 years for the poorest decile for half of the countries in the region.

This elasticity exercise is in some sense a reduced form way to think of the "last-mile" infrastructure challenge. Obviously, the "business as usual" scenario does not constitute a satisfactory option for governments in the region. The question becomes to identify the realistic components of a successful infrastructure strategy that cuts down on the time needed to achieve the necessary improvements. The next section addresses this issue.

\section{The policy challenges}

For a start, let us think of the potential gains to be had from speeding up improvements in infrastructure access. Taking again the example of water, and raising the income elasticity to 0.2 (that is above the current regional best performer) would allow the nine best-performing countries to connect all decile one households in less than 21 years. An even higher elasticity of 0.5 would allow all countries, except El Salvador, to complete that task in 16 years or less.

The elasticity used in our reduced form exercise is, in fact, the outcome of a model combining amount invested and efficiency of such investments on the supply side, with amount demanded as a 
result of price and quality options available on the demand side. However, the conventional wisdom has generally taken investment amounts as the main, if not the only, policy lever. Unfortunately, experience shows that overall investment levels are unlikely to adjust significantly in the short run.

As discussed in Fay et al. (2017), governments in the region face tight fiscal constraints. In the past decade, the combination of the commodity price bonanza, very low international interest rates, real exchange rate appreciations, and rising consumer credit, allowed major commodity exporters to rely on terms-of-trade windfalls to expand domestic demand, in particular through fiscal spending. As the recent, sharp and likely durable deterioration of their terms of trade brought down dramatically the purchasing power of their incomes, these countries (which include virtually all the major countries in South America) are now forced to reduce domestic spending.

The current level of total public investment is 3.4\%. On average, about a third of this public investment goes to infrastructure. As for public-private partnerships, the best figures available, from the World Bank PPI database, puts them at about 40\% of Latin America's infrastructure investments. However, an often-disregarded fact is that they depend heavily on government support. New figures that have been gathered starting in 2015 show that about a third of the recorded investments actually come from public sources, and about half are backed by some type of government guarantees. ${ }^{16}$ In that way, constraints to public investment spill over to private investment in infrastructure.

A recent effort to improve country-level infrastructure spending data using both national account and public budget sources (Fay et al., 2019) indicates total investments between 2 and 3.2\% of GDP, of which between 17 and 27\% correspond to private investments. Considering these levels, Latin American average investment in infrastructure is unlikely to exceed $2-3.5 \%$ of GDP in the near future, very much in line with current levels.

This leaves investment efficiency improvements, including refocusing spending "needs," reducing costs, improving cost recovery, and managing demand as the only realistic avenues to speed up infrastructure delivery in the short and medium run.

In terms of setting adequate targets or goals, consider the cases of water and electricity, highlighted in Fay et al. (2017). By one estimate (Hutton and Varughese, 2016) achieving universal access to basic water, sanitation, and hygiene by 2030, in line with the early MDG, would require an investment of only $0.05 \%$ of GDP a year through 2030 . On the other hand, achieving the much more ambitious Sustainable Development Goal of universal access to safely managed water and sanitation services by 2030 would cost 5 times more, at $0.25 \%$ of GDP, an amount equivalent to current Latin American spending on water and sanitation.

The potential for demand management, through better pricing schemes, incentives, and behavioral nudges, is probably large. The experience of Brazil in 2001, when the drought-induced energy crisis led to the implementation of a large-scale electricity saving program, is a case in point (Costa and Gerard, 2015). Faced with strong incentives, including quotas and penalties for exceeding them, households responded sharply, reducing electricity consumption. More interestingly, the policy led to a permanent and stable reduction in average electricity use of $11 \% 4$ years later, arguably through a change in consumption habits. The possibility of hysteresis, whereby temporary policies may have permanent effects by shifting agents to a different equilibrium, has clearly been underestimated when defining policy goals in the context of infrastructure investments, which lock in behaviors over a long period of time.

16 See https://ppi.worldbank.org/ 
Finally, boosting the efficiency of investment spending should be high on the agenda. It has been known at least since Pritchett (2000) that (cumulated) investment flows may translate into very different effective capital stocks, and hence services, depending on the environment in which they take place. Among the reasons for this discrepancy are government inefficiency, corruption, or departures from efficiency for redistributive motives among others. Given this, improving public investment efficiency can have direct effects on infrastructure delivery.

On the cost side, there is first an ex-ante aspect, stressed in the public investment management model (IMF, 2015). The first step toward useful policy recommendations would be to clarify what the relevant investment efficiency model is, something that is likely to be very context dependent and to collect relevant empirical evidence to test this model. Considering the two main stages of the investment process corresponding first to the planning stage, in which projects are selected and their characteristics (size, timing, and technology) are decided, and second the execution stage, in which they are carried out, this means understanding how the different stages interact, depending on the sector, the level of institutional capacity, and the level of development. For example, contrary to what is claimed in IMF (2015), focusing on the efficiency of delivery in the poorest countries is likely to be a misguided strategy. Indeed, if the two stages are strongly complementary and planning capacity is low, such efficiency gains will be useless from a social welfare point of view if the wrong projects are selected to start with.

In addition, other aspects are relevant here, such as competition policy, to the extent that competition in downstream sectors such as construction and related activities is likely to have an important impact on ex-ante costs.

Next, there is a post-construction stage of the cost issue that relates to operational efficiency. This is a crucial aspect that has much more to do with the political economy of running and delivering the service. The focus, in that case, should be on utilities managers' incentives, as regard, in particular, their relationship with politicians, soft-budget constraint issues, and consequences, for example, in terms of overstaffing and clientelism. Addressing this part of the cost structure separately may be more fruitful and would entail in particular to look at the quality of the regulatory framework.

Finally, there is much talk in policy circle about public investment efficiency improvements as catalysts for additional and sustained flows of private investment (for example, Leigland et al., 2016, and Cerra et al., 2017). However, there is again a lack of rigorous empirical evidence to evaluate the relevance of this potential channel.

Given the constraints discussed above, generating evidence to guide policymakers on the overall issue of how to improve investment efficiency appears to deserve a high rank on the list of applied research priorities.

\section{References}

Calderón C and Servén L (2003). The output cost of Latin America's infrastructure gap. In: The Limits of Stabilization: Infrastructure, Public Deficits and Growth in Latin America. Washington, DC: Stanford University Press.

Calderón C and Servén L (2010). Infrastructure in Latin America. Washington, DC: World Bank Policy Research Working Paper Series No. 5317.

Cameron AC and Miller DL (2015). A practitioner's guide to cluster-robust inference. Journal of Human Resources, 50(2): 317-373.

CEDLAS and The World Bank (2014). A Guide to SEDLAC Socio-Economic Database for Latin America and the Caribbean. Available from: http://www.sedlac.econo.unlp.edu.ar/eng/methodology.php. [Last accessed on 2016 June 01]. 
Cerra V, Cuevas A, Góes C, Karpowicz, I, Matheson, T., Samake, I and Vtyurina S (2017). Highways to heaven: Infrastructure determinants and trends in Latin America and the Caribbean. Journal of Infrastructure, Policy and Development, 1(2): 168-189.

Costa F and Gerard F (2015). Hysteresis and the Social Cost of Corrective Policies: Evidence From a Temporary Energy Saving Program. New York: Mimeo.

Davis L and Gertler P (2015). Contribution of air conditioning adoption to future energy use under global warming. Proceedings of the National Academy of Sciences USA, 112(19): 5962-5967.

Diao M, Fan Y and Sing TF (2017). A new mass rapid transit (MRT) line construction and housing wealth: Evidence from the circle line. Journal of Infrastructure, Policy and Development, 1(1): 64-89.

Dinkelman T (2011). The effects of rural electrification on employment: New evidence from South Africa. American Economic Review, 101(7): 3078-3108.

ECLAC (2014). The Economic Infrastructure Gap and Investment in Latin America. FAL Bulletin. United States: United Nations Economic Commission for Latin America.

Estache A and Fay M (2009). Current Debates on Infrastructure Policy. Commission on Growth and Development. Washington, DC: World Bank Publication.

Fay M, Han S, Lee HI, Mastruzzi M and Cho M (2019). Hitting the Trillion Mark a Look at How Much Countries are Spending on Infrastructure (English). Policy Research Working Paper WPS No. 8730. Washington, D.C: World Bank Group.

Fay M, Andres L, Fox C, Narloch U, Straub S and Slawson M (2017). Rethinking Infrastructure in Latin America and the Caribbean Spending better to Achieve More. Washington D.C: World Bank.

Fay M and Yepes T (2003). Investing in Infrastructure: What is needed from 2000 to 2010? Washington D.C: World Bank Policy Research Working Paper No. 3102.

Ferreira FH, Messina J, Rigolini J, López-Calva LF, Lugo MA and Vakis R (2013). Economic Mobility and the Rise of the Latin American Middle Class. Washington, DC: World Bank.

Galiani S, Gertler P and Schargrodsky E (2005). Water for life: The impact of privatization of water services on child mortality. Journal of Political Economy, 113: 83-120.

Gertler P, Shelef O, Wolfram C and Fuchs A (2016). The demand for energy-using assets among the world's rising middle classes. American Economic Review, 106(6): 1366-1401.

Gibson J and Rozelle S (2003). poverty and access to roads in Papua New Guinea. Economic Development and Cultural Change, 52(1): 159-185.

Hooper E, Peters S and Pintus PA (2018). To what extent can long-term investments in infrastructure reduce inequality? Journal of Infrastructure, Policy and Development, 2(2): 193-225.

Hutton G and Varughese M (2016). The Costs of Meeting the 2030 Sustainable Development Goal Targets on Drinking Water, Sanitation, and Hygiene. Water and Sanitation Program Technical Paper. Washington, D.C: World Bank.

IMF (2015). Making Public Investment More Efficient. Washington DC: International Monetary Fund.

Kohli HA and Basil P (2011). Requirements for infrastructure investment in Latin America under alternate growth scenarios 2011-2040. Global Journal of Emerging Market Economies, 3: 59-110.

Lakner C and Milanovic B (2015). Global Income Distribution: From the fall of the Berlin wall to the Great Recession. Washington, D.C: World Bank Economic Review.

Lee K, Miguel T and Wolfram C (2016). Experimental Evidence on the Demand for and Costs of Rural Electrification. Unpublished Working Paper.

Leigland J, Trémolet S and Ikeda J (2016). Achieving Universal Access to Water and Sanitation by 2030. The Role of Blended Finance. World Bank Water Global Practice Discussion Paper.

Milanovic B (2015). Global inequality of opportunity: How much of our income is determined by where we live. Review of Economics and Statistics, 97(2): 452-460.

Perrotti DE and Sánchez RJ (2011). La brecha de infraestructura en América Latina y el Caribe. Santiago, Chile: Serie Recursos Naturales e Infraestructura, CEPAL.

Pritchett L (2000). The tyranny of concepts: CUDIE (cumulated, depreciated, investment effort) is not capital. Journal of Economic Growth, 5(4): 361-384.

Rozenberg J and Fay M (2019) Beyond the Gap: How Countries Can Afford the Infrastructure They Need while Protecting the Planet. Sustainable Infrastructure. Washington, DC: World Bank.

Serebrisky T, Suárez-Alemán A, Margot D and Ramírez C (2015). Financiamiento de la Infraestructura en América 
Latina y el Caribe: Cómo, Cuánto y Quién? Washington, DC: Inter-American Development Bank.

Straub S (2008). Infrastructure and growth in developing countries: Recent advances and research challenges. Policy Research Working Paper No. 4460. Washington, DC: World Bank.

Straub S (2011). Infrastructure and development: A critical appraisal of the macro-level literature. Journal of Development Studies, 47: 683-708.

Straub S (2015). Policy lessons from the recent literature on transport infrastructure development. In: Picot AM, Grove F and Kranz J, editors. The Economics of Infrastructure Provisioning: The (Changing) Role of the State. Cambridge: MIT Press. 